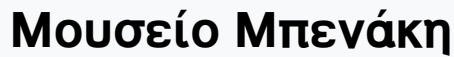

Tóp. 2 (2002)

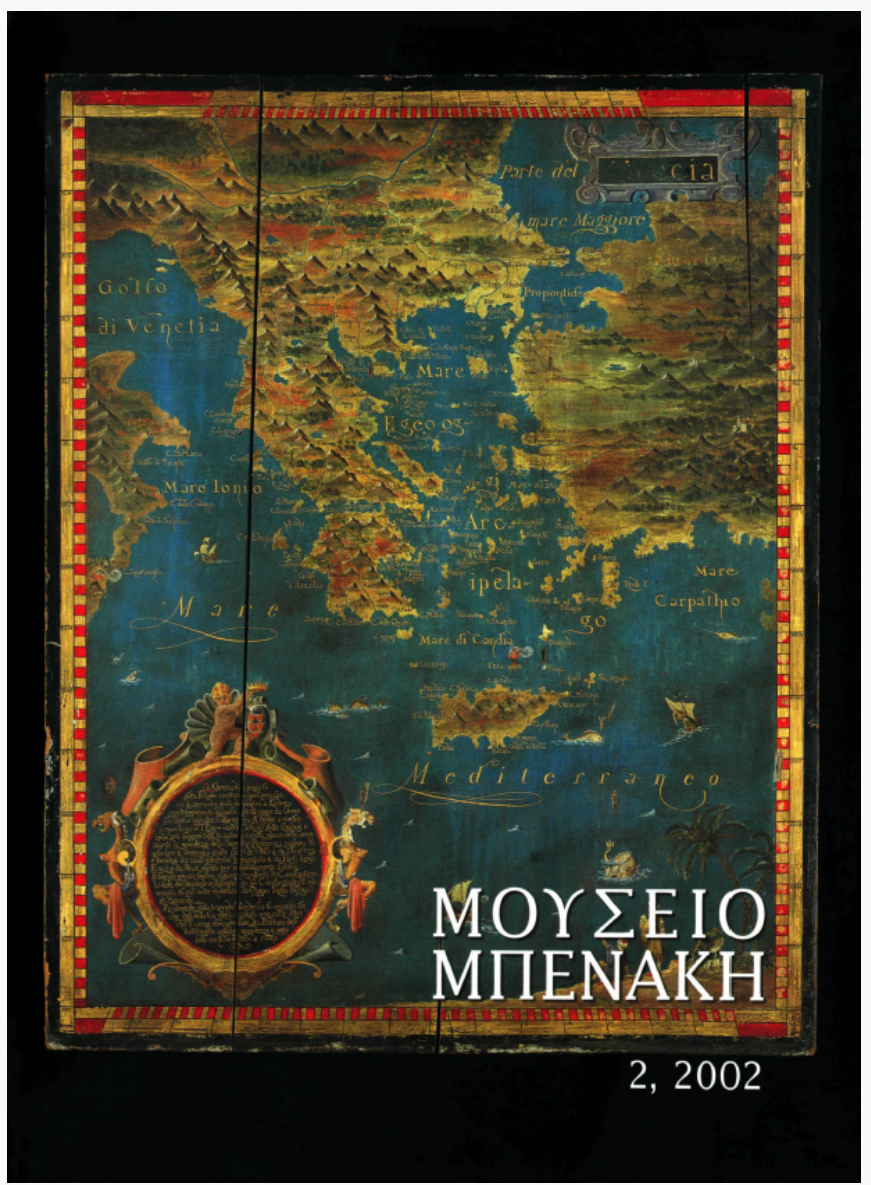

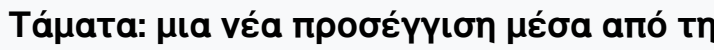

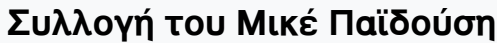

Sophia Handaka

doi: $\underline{10.12681 / \text { benaki.18194 }}$

Copyright $\odot$ 2018, Sophia Handaka

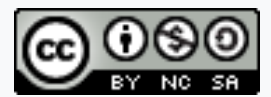

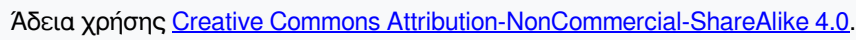

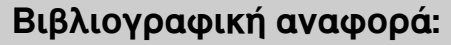

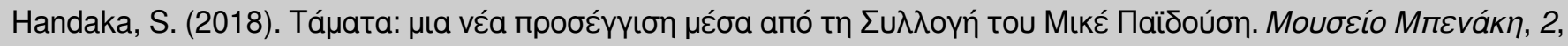
147-165. https://doi.org/10.12681/benaki.18194 


\section{Re-evaluating tamata: the Mikes Paidousis Collection of votive offerings}

The Benaki MusEum houses one of the largest public collections of Greek Orthodox metal votive offerings, known in Greek as rápata (tamata). Most of the material was generously donated to the Museum by Ioanna (Yiona) Paidousi-Papantoniou in memory of her late husband, Mikes Paidousis, in four separate instalments during the years 1999, 2000 and 2002. ${ }^{1}$

The Mikes Paidousis collection comprises 1174 objects from all over Greece. Nine of these cannot positively be identified as votive offerings, since they lack the normal characteristics of tamata, ${ }^{2}$ but the remaining 1165 objects are standard likenesses which contain examples of most of the iconographical features and production methods found in this form of Greek material culture.

Tamata are representations in miniature of human beings and objects related to human life. The collection contains 450 human figures ${ }^{3}$ and 522 parts of the body, ${ }^{4}$ as well as 55 animals (cows, horses, donkeys, goats and sheep) and 108 inanimate objects (possessions and items from everyday life); 17 offerings are icon revetments ${ }^{6}$ and 10 have a religious theme (saints, a cross and a gospel); 3 more objects have not yet been identified.

A detailed study of the objects in the collection is being carried out at the Museum with a view to establishing tamata within a context in which they acquire meaning. The main purpose of this article is to provide an introduction to the collection and to review the practice itself and the relevant literature, as well as discussing the potential problems which emerge from a systematic documentation of the objects.
Tamata are made from thin flat metal plaques, either cut into the shape of the object they portray, or rectangular in form with a depiction of the object. Their size varies from 3 to $20 \mathrm{~cm}$ in length and from 2 to $27 \mathrm{~cm}$ in width. The metals used are silver and gold for the most precious items, bronze, copper, iron, and tin, but most commonly alloys. Most have the yellow colour of oxidised silver, or brown-red in the case of alloys with a high proportion of copper. The majority have a hole at the top by which they can be hung from icons with ribbons, wire or safety pins.

Apart from 3 wax objects ( 2 eyes and 1 animal), 1 paper (a pair of hands from Yugoslavia) and 1 marble (a heart, probably French), the offerings in the Mikes Paidousis collection are made of metal. The majority are silver-plated (316) or made of other alloys, generally

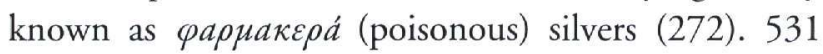
tamata are silver, ${ }^{7} 6$ gold and 14 gold-plated; there are also 12 copper, 8 tin, 4 iron and 1 bronze object.

While the techniques by which they were made are typical of traditional neo-Hellenic ecclesiastical and secular metalwork, not all tamata attain such a high degree of artistic elaboration. Many handmade figures are quite simple, though others are almost certainly the products of professional silverware workshops. They tend to share common features, mainly in the decorative patterns (abstract symbols, spirals, tufts, and floral decorations), but their general nature is unlike that of other forms of neo-Hellenic art.

Previous writers have tended to recognise three basic methods of making tamata -incision, pressing and 
casting in moulds- but the Paidousis collection provides examples of further techniques, or rather further applications of these techniques, which produce clearly distinguishable results and can thus be said to create a separate category of object. It is in fact possible to establish six categories of tamata based on produc-

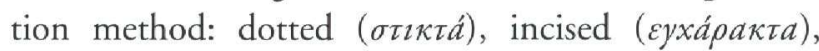

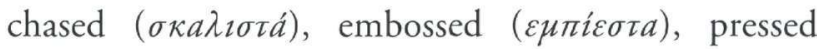
( $\pi \rho \varepsilon \sigma a \rho \imath \tau \tau a ́)$ and cast in moulds ( $x v \tau a ́)$.

Earlier studies have sometimes included within the category of incised tamata the oldest type of offering, in which the figure was formed by punching dots on the back of metal plaques. Such "dotted" offerings (as they are informally known) normally have stylised or symbolic designs. The Paidousis collection contains 209 examples, a significant number considering their rarity today.

"Incision" is the method of engraving a design on the face of a normally flat plaque with a sharp tool or nail. There are 123 tamata produced by this technique in the collection. The carving on "chased" offerings is thicker, and normally made with a chisel. The collection includes few such examples (20), but they are interesting because they present a particular style of their own.

A number of objects in the collection are incised on the front and repoussé or hammered on the back, so as to create a rounded shape. Such "embossed" figures form a separate category, different from, but sharing certain characteristics with, the more recent offerings that are "pressed" in a brass uterus. These latter, unlike the embossed examples, have an identical, stereotyped appearance. The collection contains 374 embossed and 427 pressed offerings.

The final category, offerings "cast in moulds", are rarer, possibly because they use a much larger quantity of metal. Cast offerings resemble pressed in iconography and style. The collection contains 12 examples of this type.

\section{History of the Collection}

The Paidousis began collecting in 1959 and they continued systematically until 1974. Starting off in the Athenian flea market (Monastiraki) - where at the time tamata could be found in considerable quantities both among antique dealers and in small shops- they were soon picking up objects on their travels throughout Greece, mainly in the islands (Crete, Chios, Mytilene, Patmos, Samos, Santorini, Sifnos, Skiros, and Spetses) but also in mainland Greece (Volos, Ioannina, Thessaloniki). They normally bought from antique shops, but occasionally they collected objects from small churches in the countryside, after obtaining the priest's approval and leaving a gift of money for the church. ${ }^{8}$

Their interest soon extended to all forms of tamata, with special emphasis on human figures and parts of the body, since they were planning to produce a detailed study on the medical aspect of offering.' Their aim was to assemble a wide range of figures, as the content of the collection shows, but they also made a point of including variants of objects already in their collection, a policy that facilitates comparative study today.

All the objects in the Mikes Paidousis collection have been registered, documented, catalogued, photographed and digitally stored, and some are on display in the Benaki Museum, in the galleries dealing with everyday rural life. ${ }^{10}$

\section{Definitions}

In Modern Greek, the word táua refers to an offering, usually directed to a particular saint, in reciprocation for the granting of a favour. It is a promise in the form of a prospective offer, entered into when a person or his close kin are in danger or in sickness, or an act of

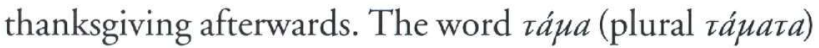
signifies both the act of offering and the object itself, the votive offering. It derives from the verb táoow (now $\tau a ́ \zeta(\omega)$, which means "to promise to give to the divine", "to offer", "to keep or execute", "to provide something as an offering". ${ }^{11}$ The word has a wider usage in everyday language, illustrated by its inclusion in popular

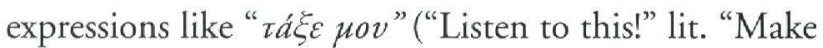
a tama for me"), used by someone about to announce

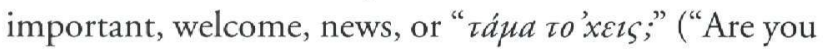
really going to?" lit. "Are you making a tama for this?"), an expression addressed to a person determined to carry out a particular task. In different ways, the semantics of the word contain the idea of a response to a vow.

Many words exist in Greek to describe offerings, ${ }^{12}$ but for the purpose of this study I propose to refer to all the material as tamata; this term seems to be the most appropriate as it suggests all aspects of the phe- 


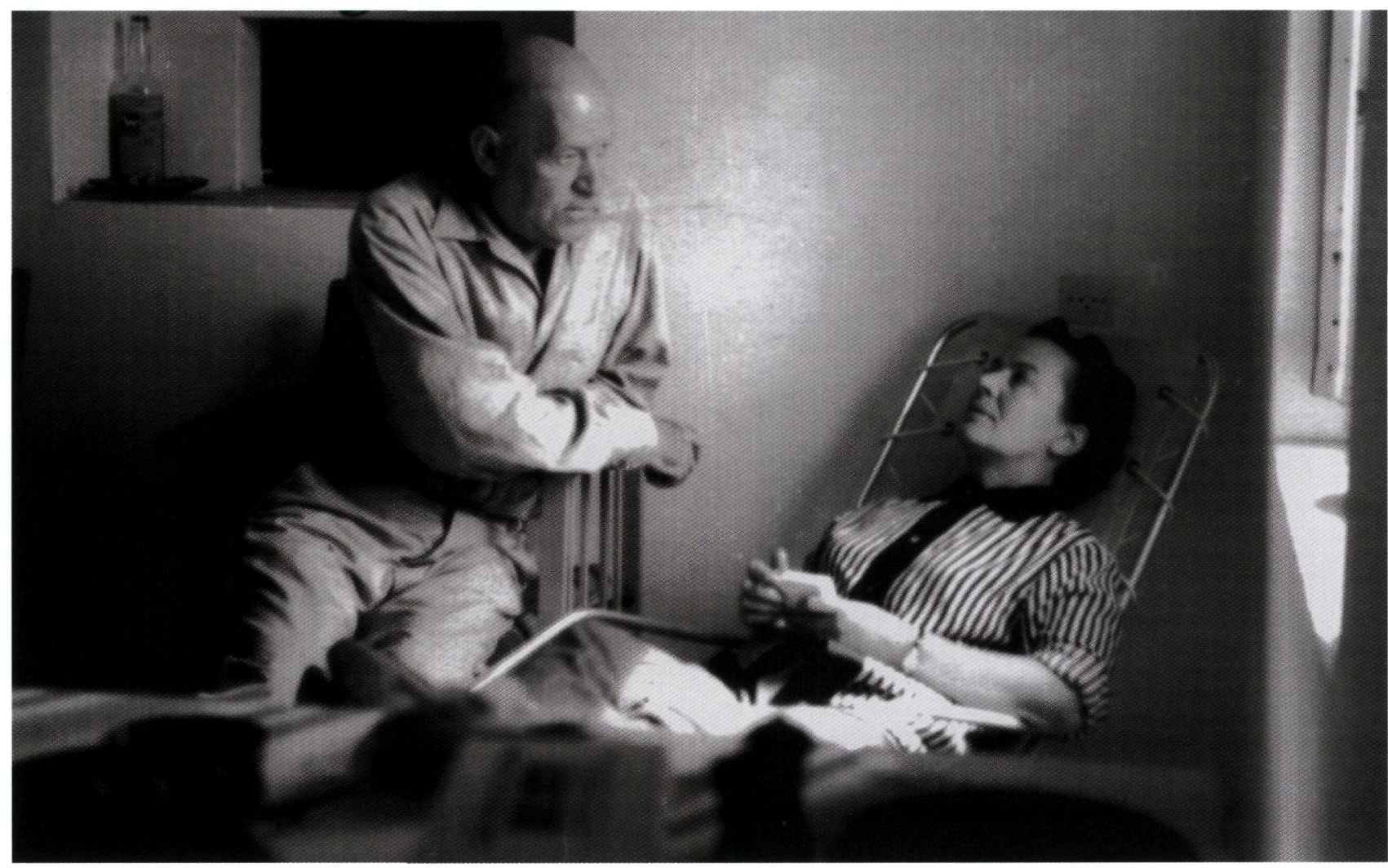

Fig. 1. Mikes and Yiona Paidousis in their summerhouse on the island of Spetses in the late ' 60 s.

nomenon: desire, inclination, belief, practice, and the manifestation of these in material terms. ${ }^{13}$

The votive tradition in Greece

Tamata are religious objects used in a process of human communication with the divine, given material form through the practice of offering. Offering to the divine is a means of dealing with the adversities of life that is regularly practised within the Greek Orthodox tradition and further afield. It can take many forms and may involve multifarious procedures, all pertaining to the basic need for divine intervention in the resolution of distressing circumstances.

An offering may be bestowed before, during or after a crisis, or made for general future welfare. Propitiatory offerings are prompted by times of sickness or danger, when protection is urgently needed. In the case of offerings promised at a critical period, the devotee is fully dependent on the divine. Thank-offerings may represent the fulfilment of vows made before or during a time of distress, or be donated afterwards as an expression of gratitude towards the saint.

Offering presupposes a system of exchange. The means of exchange may be spiritual -in which case the vow pledges a mode of action with a religious connection- or material, if the vow requires the presentation of objects as gifts. ${ }^{14}$ Spiritual offerings involve giving the self figuratively, either through suffering voluntary hardship -by the wearing of black, fasting or acts of veneration such as genuflection- ${ }^{15}$ or by long-term selfenslavement $(\sigma \kappa \lambda \dot{a} \beta \omega \mu a)$ to the service of God. ${ }^{16}$

Material offerings may be either symbolic, such as financial contributions to the church for specific or general protection; or votive, in which case particular objects are donated. The latter may be expendable -such as candles, incenses, oil, bread, pies ${ }^{17}$ and other raw or cooked food $-{ }^{18}$ or non-expendable.

Non-expendable votive offerings are usually of greater value. Templons, lamps, candlesticks, precious altar coverings and other ecclesiastical objects may be offered 

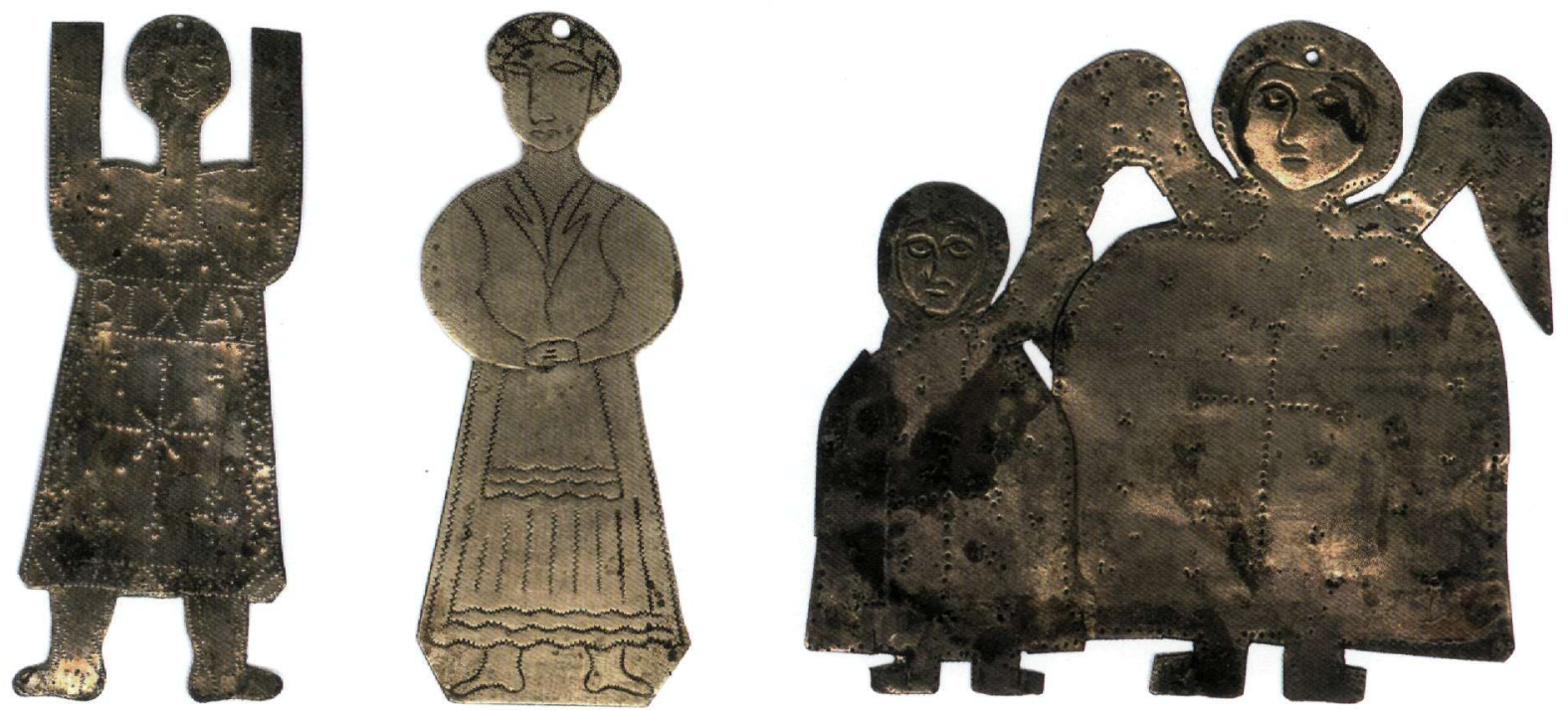

Fig. 2. Silver dotted tama cut in the shape of a human figure with the hands raised in supplication and the name BIXA inscribed at the centre $(9.8 \times 3.6 \mathrm{~cm})$. Collected in Chios, end of 19th century. Athens, Benaki Museum 36520 .

Fig. 3. Silver incised tama cut in the shape of a female figure wearing a traditional Greek dress $(7.6 \times 3 \mathrm{~cm})$, end of 19 th century. Athens, Benaki Museum 36579.

Fig. 4. Silver dotted tama cut in the shape of two figures holding each other, possibly an angel and child $(8.2 \times 9 \mathrm{~cm})$, end of 19 th century. Athens, Benaki Museum 36571.

to a church in accordance with a vow, and most Greek churches contain examples of this kind. Such gifts are often anonymous, but sometimes literary sources provide information as to their background -General Makryiannis' memoirs, for instance, describe how he dedicated a silver lamp to St John as a boy. ${ }^{19}$

The full or partial covering of icons with silver

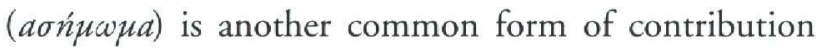
to the church. Silver revetments -crowns, halos, hands and legs are the most common types- are attached to the images of saints, and these are often to be found in collections. They resemble ecclesiastical art in style, and are distinguishable from other tamata by certain characteristics indicative of their special nature, being made of purer and more pliable silver and having multiple holes for attachment to the icon (fig. 12). ${ }^{20}$

Votive offerings also include more personal gifts, such as jewellery, clothing and other objects of particular value to the devotee, either sentimental or material. A more recent observance is to leave money beside the icons of saints.

Most votive offerings are objects of Greek material culture, which may or may not be specially produced, and may or may not have artistic value. All offerings have in common the feature that they involve the offeror in some form of expenditure which is bestowed on the divine in exchange for some form of return. Material offerings have an explicit function as permanent reminders. The objects we shall be examining, metal images, form a specific category in that they are specially produced for the purpose of offering, and attain some degree of artistic value.

\section{Scholarly evaluation}

Traditional Greek art began to be studied systematically at the beginning of the twentieth century when intellectual circles started to take an interest in popular artefacts as a previously undiscovered form of curio. Attention was mainly paid to the beautiful and the elaborate, and so, unlike objects such as textiles, jewels, pottery and woodcarvings, tamata lacked the credentials to attract the researchers' interest. Their comparative lack of artistic elaboration and aesthetic appeal, together with the fact that the practice was not in danger of extinction 

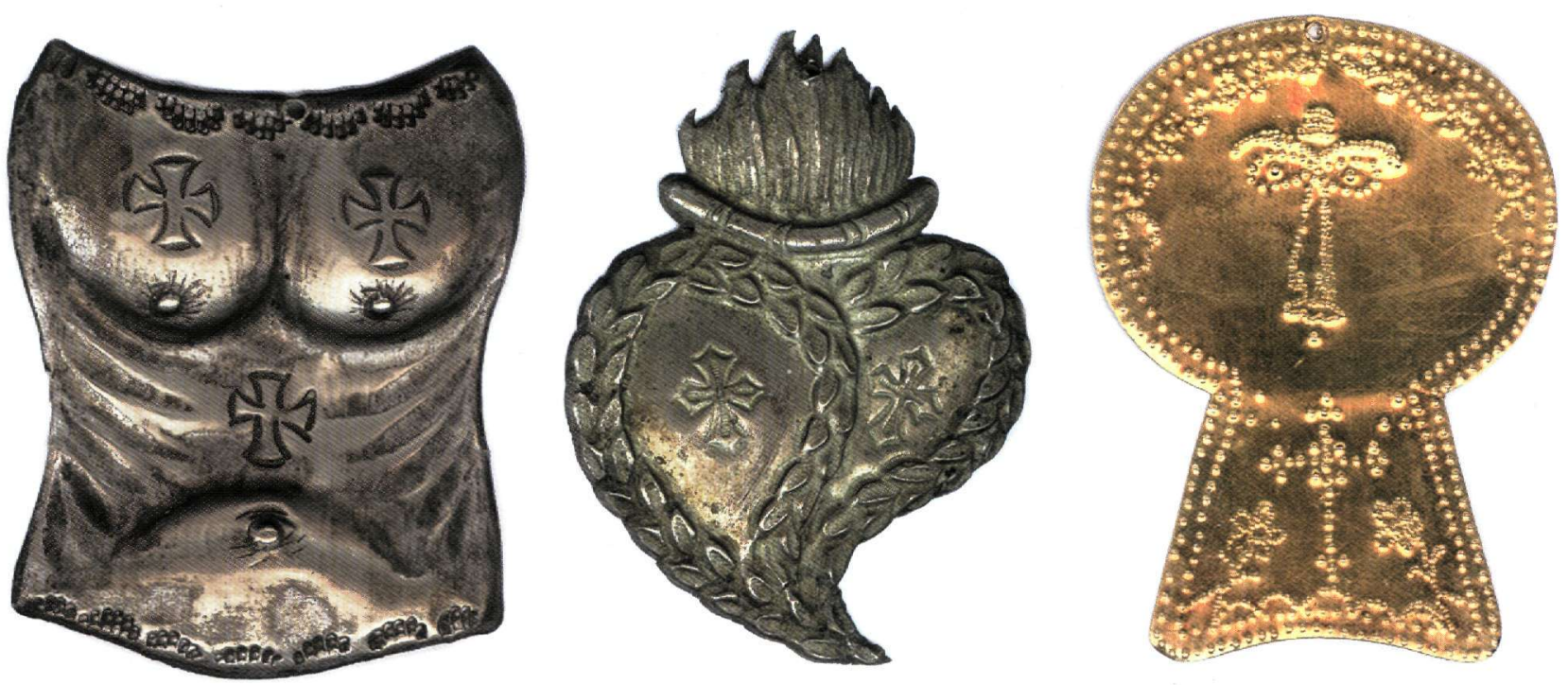

Fig. 5. Silver embossed tama cut in the shape of a torso decorated with three 'Byzantine' crosses $(5.2 \times 4,2 \mathrm{~cm})$, beginning of 20th century. Athens, Benaki Museum 36987.

Fig. 6. Silver embossed tama cut in the shape of a flaming heart with two 'Byzantine' crosses $(7 \times 5.1 \mathrm{~cm})$, beginning of 20th century. Athens, Benaki Museum 37292.

Fig. 7. Gold dotted tama cut in the shape of a head with rich decoration $(6.2 \times 4.6 \mathrm{~cm})$. Collected in Chios, end of 19th century. Athens, Benaki Museum 36936.

and was still familiar to all, ${ }^{21}$ doomed them to receiving the minimum of attention.

Tamata have been classified as objects of Greek popular art with a religious character. As a category of art they have received little attention, however, and they have not generally been seen as having technical or artistic interest. The practice of offering has sometimes been included in general discussions of Greek popular traditions, but only in passing and in order to stress its affinities with the ancient world. ${ }^{22}$ Any evaluation of the objects themselves has been limited to the basic characteristics of votive offerings and their historicity. Such discussion has taken place at random intervals only, and has not aimed at scholarly analysis of the evidence or at setting it in the context of other such studies. However the following is a summary of such material as has been published to date.

In the earliest known article dedicated to tamata,

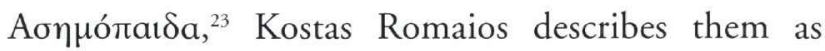

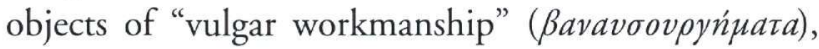
"prosaic pieces of work slightly more successful than you could expect from a seven-year-old child". ${ }^{44}$ A year later Nikolaos Politis wrote a criticism of Romaios's

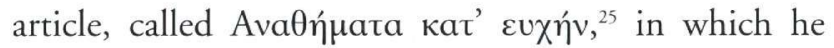
argues that tamata may be the mediocre productions of third-rate craftsmen, but they are important because they touch upon human feelings and ancient custom.

A reversal of this attitude towards tamata appears in the 1950s with Rudolf and Hubert Kriss' book on pilgrimage in contemporary Greece and Italy. The writers devote a chapter to tamata, in which they describe and illustrate offerings from all over Greece without detailed analysis, but with pertinent comments. ${ }^{26}$ In a short arti-

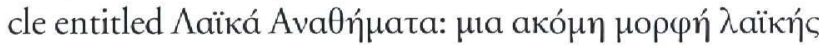

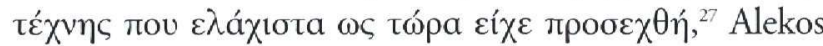
Fassianos and Nora Archelaou extol the beauty and simplicity of these under-represented examples of popular expression.

The first book devoted to tamata came out in $1971 .^{28}$ In presenting votive offerings as simple Greek artefacts, the author, Nikos Papadakis was the first to appreciate their significance. ${ }^{29}$ Against the background of his own collection, fully illustrated in the book, he describes the history of the practice and the different methods of 

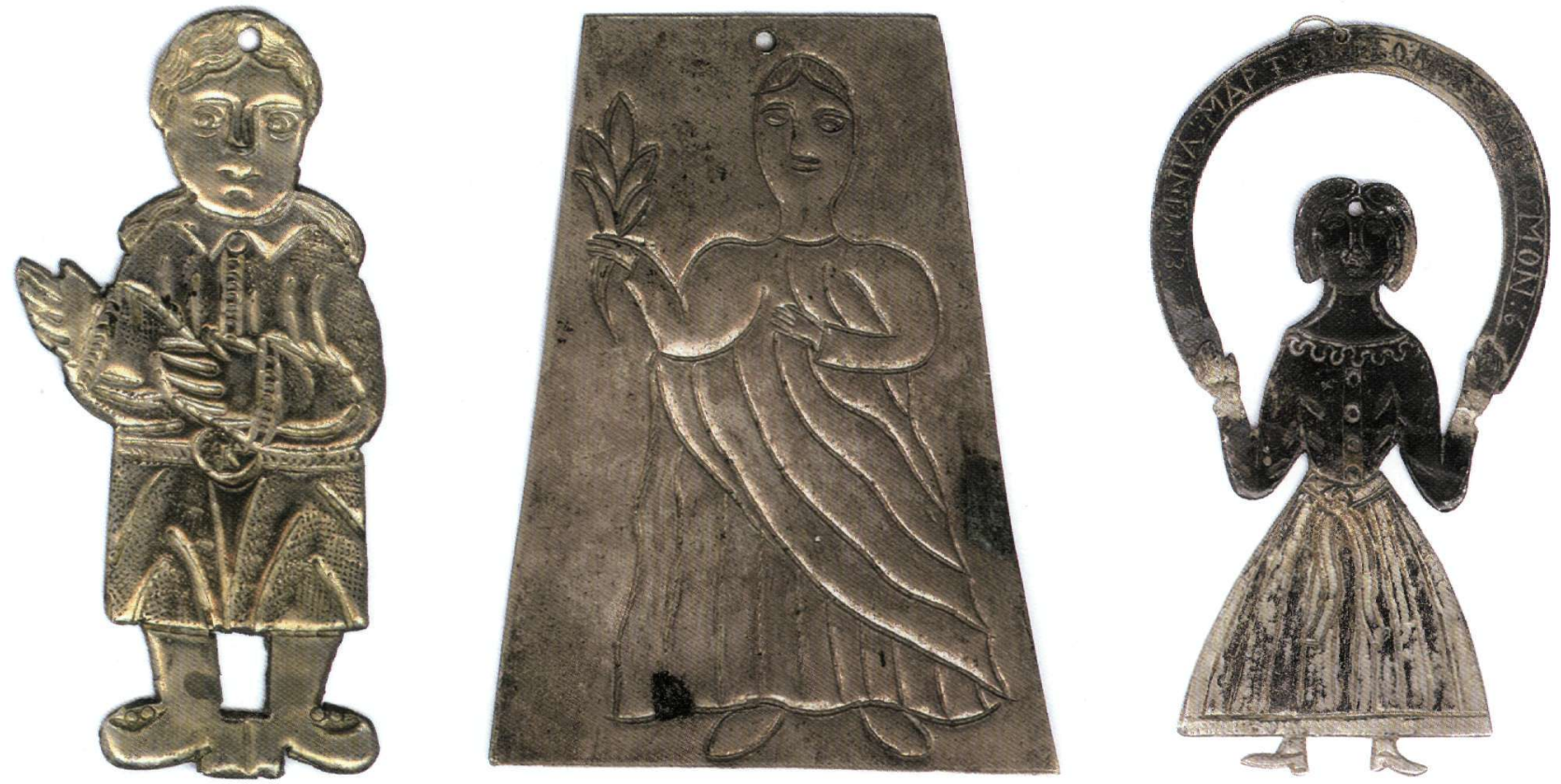

Fig. 8. Silver embossed tama cut in the shape of a male figure believed to represent the neo-martyr Saint George of Ioannina $(6.8 \times 3.5 \mathrm{~cm})$. Ioannina, end of 19th, beginning of 20th century. Athens, Benaki Museum 36830.

Fig. 9. Silver trapezoid tama with a chased representation of a human figure wearing a long tunic $(7.1 \times 5.3 \mathrm{~cm})$, end of 19th century. Athens, Benaki Museum 36601.

Fig. 10. Silver chased tama cut in the shape of a teenage girl holding a loop that has the inscription [1]875 EPMHNIA MAPTON ETON EZ API@MON 6 (10.3 x 5.4 cm), 1875. Athens, Benaki Museum 36905.
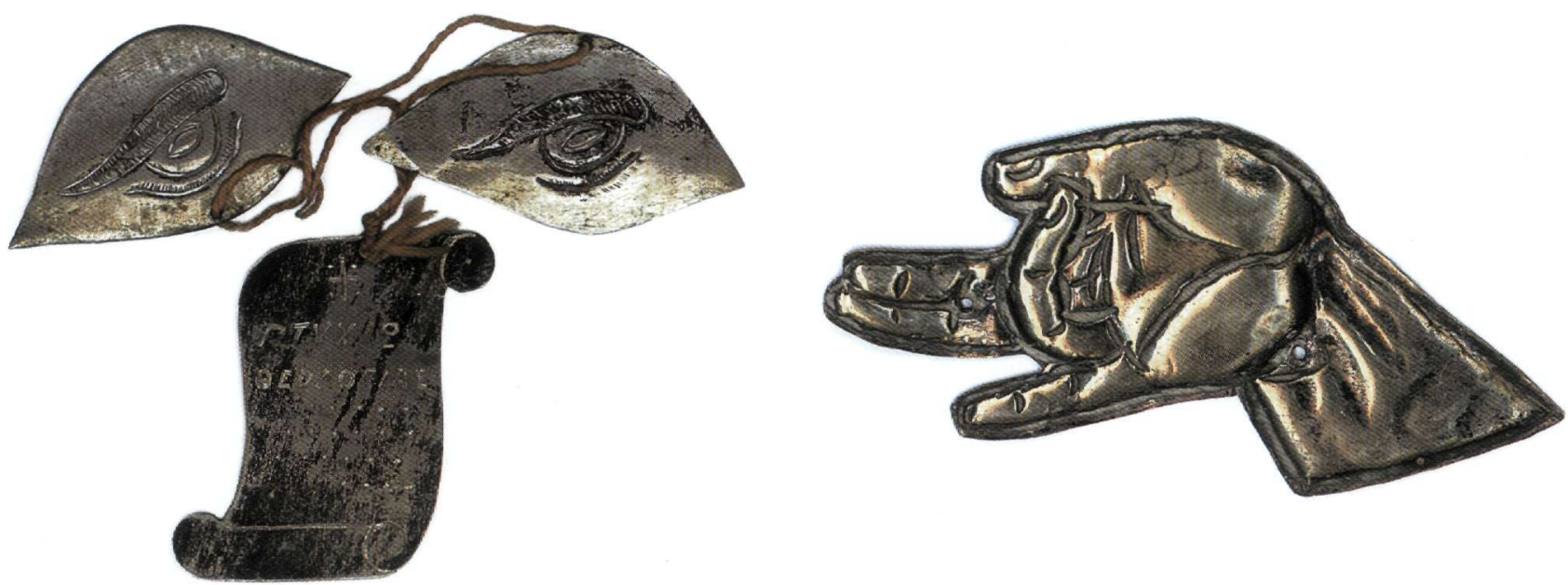

Fig. 11. Silver incised tama cut in the shape of a diploma that has the inscription ПТYXI $\Theta E O \Lambda O Г I A \Sigma$, tied together with two embossed tamata representing eyes $(3.9 \times 3.7 \mathrm{~cm}, 2.2 \times 4.4 \mathrm{~cm}, 2.3 \times 4.3 \mathrm{~cm})$. Collected in Spetses, beginning of 20th century. Athens, Benaki Museum 38721 a- $\gamma$.

Fig. 12. Silver embossed tama cut in the shape of a blessing hand $(14.3 \times 3 \mathrm{~cm})$, beginning of 20th century. Athens, Benaki Museum 37138. 
producing offerings. Half of the book consists of illustrations, but he adds comments in which he declares his belief in the authenticity of handmade tamata and denounces the decadence of more recent mass-produced examples. ${ }^{30}$ Some of the ideas he expresses in his commentary are difficult to prove ${ }^{31}$ but he also raises interesting points for further discussion. ${ }^{32}$

Not long afterwards another amateur folklorist, Zaharias Stellas, devoted a chapter of his book on Parian folk art to hand-made votive offerings. ${ }^{33}$ Using simple language, with frequent reference to popular sayings and oral recollections, he presents a romanticised view of votive offerings as the ultimate in folk art. The unsophisticated materials and workmanship are evidence of the inability of donors to afford silver and to find suitable craftsmen to work $\mathrm{it}^{34}$-he notes- but the true value of offerings lies in the donor's intentions and not in the material worth of the object. Admittedly, they

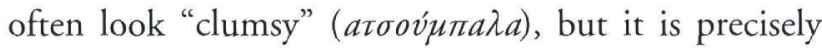
this feature which makes them so real..$^{35}$

A 1982 study by Alekos Florakis concentrates on boat-shaped tamata. ${ }^{36}$ The writer gives a detailed account, filled with information and scholarly analysis, of these and other types of marine offerings. He shows us the most popular, finest and most unusual examples, concentrating on those to be found in the Church of the Annunciation on the island of Tinos.

The latest publications ${ }^{37}$ on votive offerings are two catalogues with introductions written by Maro Kardamitsi-Adami, one focussing on human figures

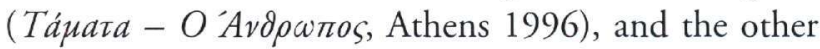
on the remaining "miracles" (Táuata - @áuata, Athens 1996). The author takes a substantially different approach in assessing the place of votive offerings in neo-Hellenic art, disagreeing with earlier writers who considered the objects to be insignificant, and arguing that if their only value was faith, then the believer could just as well deposit a gold coin or light a candle. ${ }^{38}$ Kardamitsi-Adami is the first writer who pays equal attention to pressed tamata, and many of the objects in the collection she is presenting are of this type. She has also extended her research to two particular groups of tamata: depictions of houses ${ }^{39}$ and female figures..$^{40}$

Certain other writers have included offerings in discussions of Greek traditional metalwork. Markos Botsaris believes that they do not constitute art, since they were
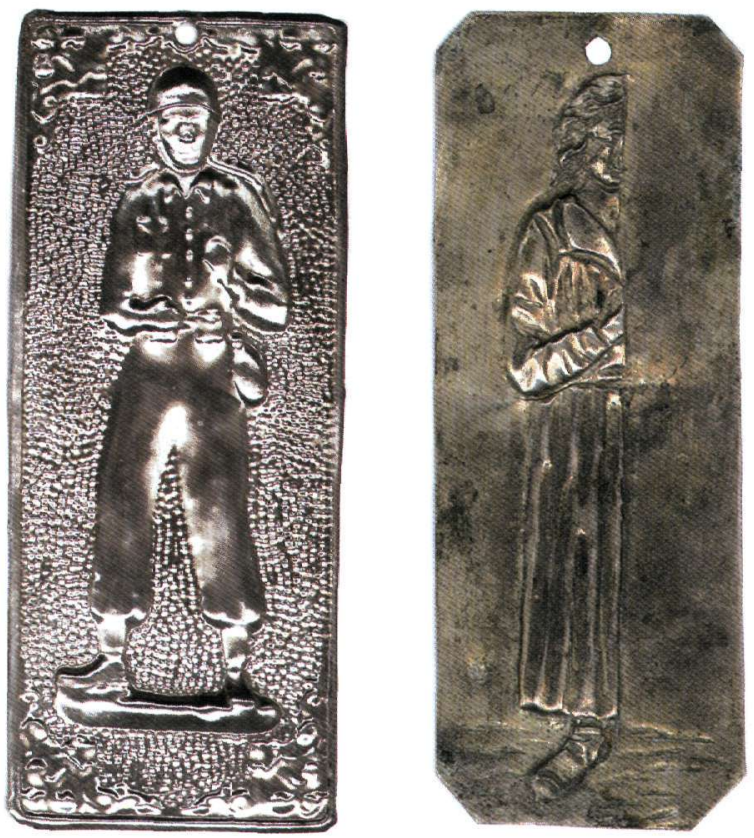

Fig. 13. Silver-plated rectangular tama with a pressed representation of a soldier in uniform and full gear $(11.5 \mathrm{x}$ $4.7 \mathrm{~cm}), 1940 \mathrm{~s}$. Athens, Benaki Museum 36765.

Fig. 14. Silver rectangular tama with a pressed representation of a woman cut vertically in half $(12.5 \times 4.7 \mathrm{~cm})$, beginning of 20th century. Athens, Benaki Museum 36665.

produced by ordinary people. He argues that their purpose was magical and that they were really a form of bribery: the rich could afford to commission aesthetically pleasing items from professional craftsmen, he remarks, but any artistic qualities were accidental. ${ }^{41}$ Dimitris Stamelos contends that tamata should be considered as a form of Greek art, and were indeed often made by well-known silversmiths. ${ }^{42}$ Yianoula Kaplani sees them as a separate category of silverware, "an amalgamation of a variety of convictions and social bonds." ${ }^{43}$ In the catalogue of a joint exhibition between the Benaki Museum and the Museo Nazionale delle Arti e Tradizioni Popolari (Rome), Luciano Blasco categorises votive offerings as metalwork with a religious character, endowed with magical-preservative attributes like amulets. ${ }^{44}$

In general, tamata have no clear position in the study of traditional Greek art and material culture. They fall outside accepted categories, such as silverware, secular art, and religious art (or, if they are not art, religious 

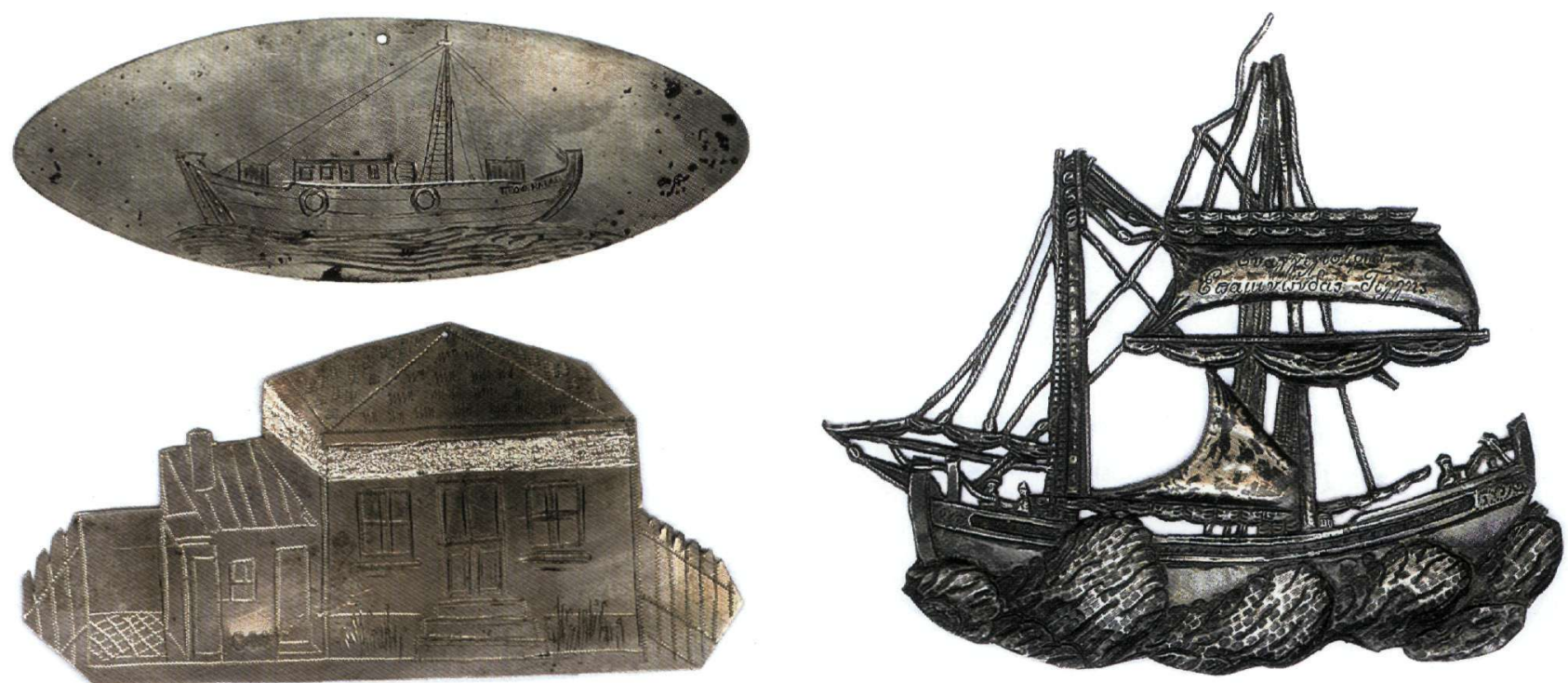

Fig. 15. Silver oval tama with an incised representation of a fishing boat with its name ПРОФ. НАIA $\Sigma$ incised on the front $(5.7 \times 14.7 \mathrm{~cm})$, beginning of 20th century. Athens, Benaki Museum 36481 .

Fig. 16. Silver incised tama cut in the shape of a house $(4.3 \times 8.7 \mathrm{~cm})$. Collected in Thessaloniki, beginning of 20th century. Athens, Benaki Museum 36404.

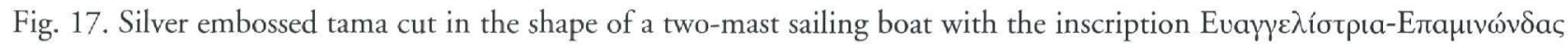
TÉ $\lambda \lambda \eta \zeta$ on the mast. On the bottom right, the turgha is imprinted $(16.5 \times 20 \mathrm{~cm})$. Collected in Chios, end of 19th century. Athens, Benaki Museum 36254.

material culture). Most publications limit themselves to presenting illustrations of these popular works, and adding highly romanticised footnotes. Studies only appear on the scene haphazardly, when a particular collection is "discovered".

Tamata tend to be taken for granted as individual objects, and they are only discussed as examples of a particular trend. Most writings on the subject are general and descriptive; they make no attempt at propounding serious arguments, and the limit of their ambition is to stimulate future studies. With this background, there has been no discussion on basic artistic issues such as the origin, chronology, morphology and style of the objects. This situation reflects the general obscurity which overshadows the study of neo-Hellenic art in general, and silverware in particular. As Angelos Delivorrias has noted in the case of jewellery, there is a notable absence of comparative parallel analysis based on the historical context in which the items first appeared. ${ }^{45}$ But before we turn to the implications of such problems on the classifica- tion of tamata, let us first get acquainted with the objects themselves.

The objects of study

An examination of the various techniques used in producing tamata suggests a basic distinction between simple handmade artefacts, which are mainly rural, and the more elaborate urban workshop tamata. Even so there are a number of objects, employing multiple techniques, which defy strict categorisation.

Dotted tamata are made by punching dots from the reverse side of the metal, which has a soft texture. ${ }^{46}$ All of them are cut into the shape of the figure portrayed, though sometimes rather crudely. Some objects are very simply decorated, while others have ornamentation over the entire surface.

The objects depicted are mainly human beings and parts of the body, but houses and animals can also be found. Dotted tamata are particularly interesting as they represent the simplest and most abstract designs, in that 

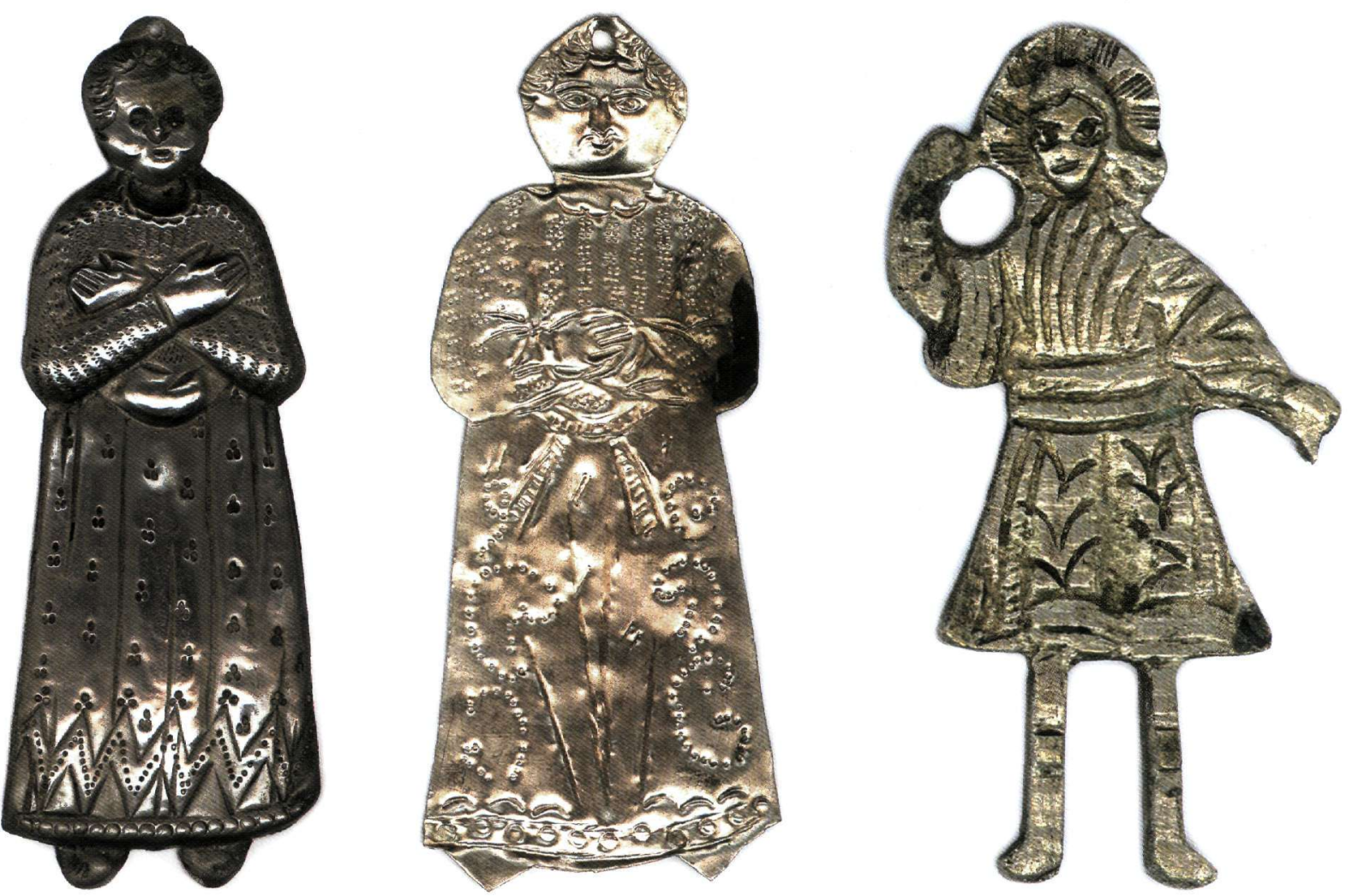

Fig. 18. Silver embossed tama cut in the shape of a female figure with her hands crossed on the chest $-\mathrm{a}$ characteristic figure of the eastern islands and Asia Minor offerings $(10.6 \times 3.9 \mathrm{~cm}$ ), beginning of 20th century. Athens, Benaki Museum 36641 .

Fig. 19. Silver-plated embossed tama cut in the shape of a male figure, probably a priest $(10 \times 4.2 \mathrm{~cm})$, beginning of 20th century. Athens, Benaki Museum 36711.

Fig. 20. Silver cast tama in the shape of a female figure, probably an angel $(5.8 \times 3 \mathrm{~cm})$, beginning of 20 th century. Athens, Benaki Museum 36636.

details are not rendered plastically. In this morphological type there is no uniform style and their features depend on local influences, as far as we can judge from the information available. ${ }^{47}$ In reality, each object is unique.

Human figures have a standard triangular shape, with the head, hands and feet protruding. Hands may be raised in supplication or lowered parallel to the body. They usually stand in an attitude of piety, and are sometimes given facial expressions. Occasionally, two dots indicating the breasts facilitate the designation of sex. ${ }^{48}$ Standard features include costume - a skirt and blouse or waistcoat for the female, ${ }^{49}$ and trousers or suits for the male.

The dotted group contains human figures with long hands and broad shoulders, which have been identified as angels. However, these figures are also said to represent children ${ }^{50}$ and in view of the absence of children among dotted tamata, this may well be correct. One item unique to the collection portrays an angel embracing a child (fig. 4).

Dotted parts of the body are also rendered in a stylised manner. Legs are depicted in dotted outline from the knee downwards, often with an indication of the knee and ankle, and sometimes the toes. Hands are similarly represented starting at the wrist or the elbow, and usually with identifiable fingers and knuckles. Eyes are normally almond-shaped with another eye or a cross placed in the middle. ${ }^{51}$ Ears are stylised, with a depiction of the inner curve of the organ. The one head in the collection is very elaborate, with a beautiful 
representation of facial features and hair, and a floral decoration on the neck (fig. 7). Torsos are stylised, usually oval and cut flat at the top, or rectangular, with indications of stomach, breasts, navel and ribs. Separate breasts appear in two forms: lateral, with the nipple at the bottom, or frontal, with a dot in the centre. ${ }^{52}$ Hearts are given a symbolic form consisting of a heart shape with a dotted outline and a cross in the middle.

Animals are meticulously portrayed, with detail on the harness, and they are often given human facial characteristics (fig. 21). The only inanimate designs are symbolic renderings of houses, lucky horseshoes, and belts. ${ }^{53}$

Apart from the basic figure, certain dotted tamata have further features which may be indicatory (e.g. an arrow pointing to the relevant part of the body), symbolic, or purely decorative. These have the expressive quality of abstract images. The cross is the most consistent decorative pattern and most objects have at least one. Crosses may be simple, formed of two series of dots, or more elaborate, in imitation of large ecclesiastical crosses with a base, edges and rays. On human figures, the cross is usually depicted on the skirt or hanging from the neck by a chain, while on parts of the body it is in the centre. Other decoration includes spirals, circles, flowers, and abstract designs, with lacy or dotted ornamentation commonly found on the edges.

A number of dotted objects have features made with different techniques; of these, human figures with a pressed, incised or chased head are especially interesting. Sometimes a particular detail on the clothes is made by incision, and names or initials may be dotted or incised. Very few dotted offerings display workshop marks.

On incised tamata, the maker scratches the features with a nail or other sharp tool on the front side of the plaque. Incised objects may have a pattern of lines, or a fishnet or zigzag design. In this type, the number of rectangular plaques and plaques cut to the shape of the figure is broadly similar.

The subjects represented are similar to those mentioned above in the context of dotted tamata, but the categories of human figures are much more clearly identifiable -men, women and children can be easily distinguished. One may suggest that two basic stylistic patterns can be differentiated, depending on whether the objects are the work of amateur or professional silversmiths. The simpler form resembles dotted tamata stylistically, apart from the use of incision. The professional offerings are more ornate, sometimes introducing novel elements, and there is evidence that they come from city workshops.

Most of the simple human figures are incised in a fishnet pattern, a procedure that results in an awkward design. Many combine incision with punched dots, usually on the outline. They stand in repose, with hands crossed on the chest. The more elaborate human figures aim at a more representational and artistic portrayal. In this morphological type parts of the body tend to be simply made, while additional forms (fingers, mouths) appear, though the customary hands, hearts, legs, torsos, heads and eyes are still common. Depictions of property can also be divided into simple and more elaborate creations, and designs include boats, envelopes, wedding garlands, books, 'thank you' notes and an aeroplane. ${ }^{54}$ An interesting offering consists of a diploma tied to two eyes with a yellow thread and inscribed ПTYXI $\Omega$ $\Theta \mathrm{EO}-$ $\Lambda$ ОГІА $\Sigma$ (for a theology degree) (fig. 11). ${ }^{55}$

Simple incised tamata contain virtually no decoration, while that on the professionally-made items is more naturalistic. Crosses still predominate, but candles are sometimes held by human figures, as are other objects relating to everyday activities. In general, design and decoration are more realistic.

A small number of objects are chased with a chisel on thicker metal -four women, a St George (fig. 8) and an old man in village clothes. Kardamitsi-Adami has stated that a motif claimed to be of Byzantine origin depicts a man wearing a palladium, with his hands raised in a typical Roman gesture of salutation. There is an almost identical figure in the collection which looks more like a woman, however (fig. 9). ${ }^{56}$ A plaque depicting a girl holding a hoop with the date 1875 inscribed on it is the oldest item in the collection which can be dated with certainty (fig. 10). Apart from one head and two eyes, the only chased parts of the body are hands, which are probably icon revetments. ${ }^{57}$

Embossed tamata involve the techniques both of incision and of pressing or hitting. They are repoussé on the back, using either dies or a hammer, and incised on the front, to outline the design and create additional features. Some are very similar to the pressed offerings in appearance; others follow the style of the incised variety and are more curved. 

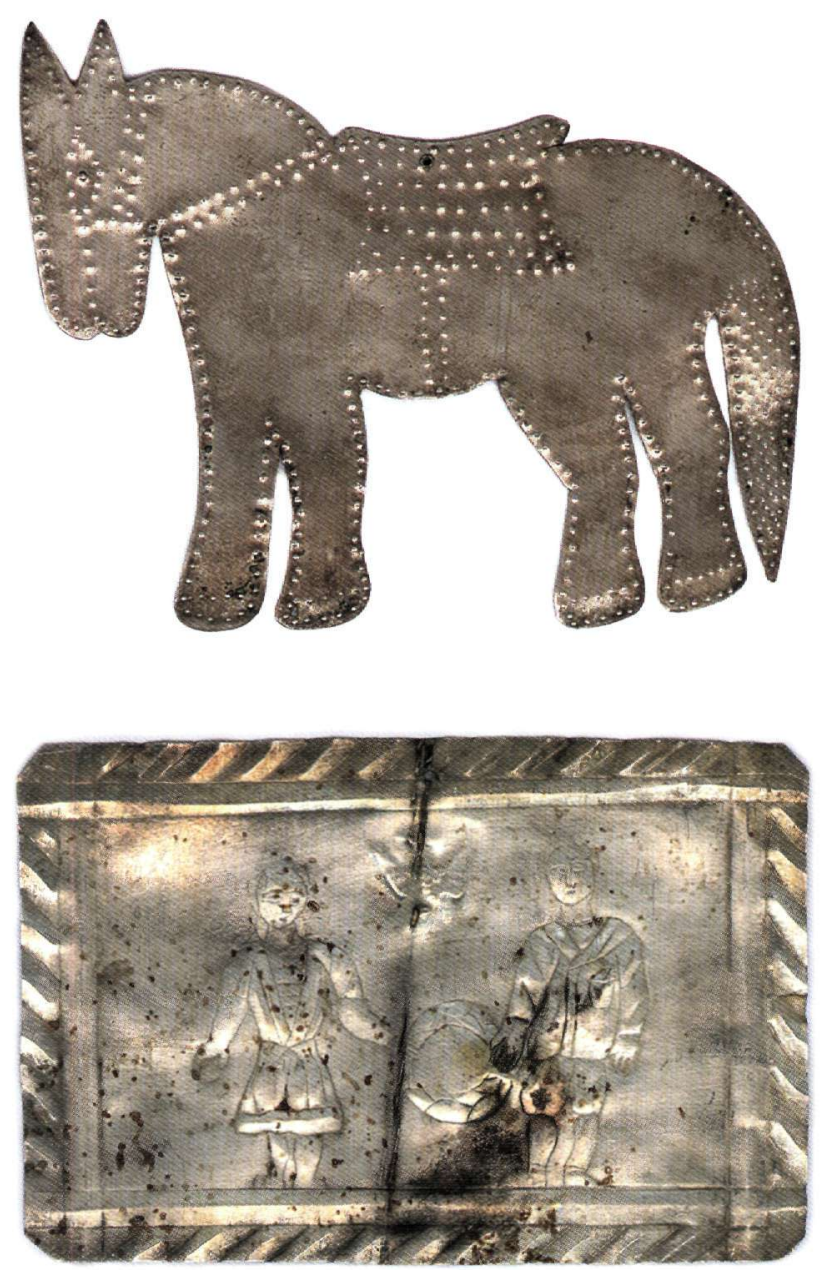

Fig. 21. Silver dotted tama cut in the shape of a horse with the harness $(7.5 \times 9.5 \mathrm{~cm})$. Collected in the church of Kokorovilia in Chios, end of 19th century. Athens, Benaki Museum 36451.

Fig. 22. Silver rectangular tama with an embossed representation of a boy and a girl holding a wreath, and a pigeon on top $(8.2 \times 12.5 \mathrm{~cm})$. Ioannina, beginning of $20 \mathrm{th}$ century. Athens, Benaki Museum 36829.
In this category we find the largest variety of styles. Once again, certain objects are more elaborate than others, and display exceptional workmanship. Morphological variety also depends on the makers' creative talents and their ability to give individual shape to the votary's requirements. Such inventiveness is strikingly displayed in objects which attempt innovative representations, such as two children holding a wreath, and a woman cut in half horizontally (figs 22,14 ).

The iconography of embossed tamata is again comparable with that of the categories already mentioned. Figures, clearly male or female, stand in repose with their hands crossed over their chest, or with their arms bent and holding a candle or a cross. They are dressed in rural or urban clothing, depending on the social position of the votary. New categories of individuals appear, such as babies, boys, girls, and young men and women who can be distinguished by their dress. ${ }^{58}$ Two male figures in long ornamented garments may represent priests (fig. 19).

Parts of the body are similar in style to the human figures. Embossed torsos differentiate between male and female forms. Some display European stylistic influences, while others are stylised and symbolic. Heads, eyes, ears, hands and legs range from simple handmade depictions in rectangular frames to objects that clearly follow specific artistic trends. Hearts are still rendered in a symbolic manner, but they now have a flame on top, an obvious indication of Catholic influences (fig. 6); $;^{59}$ one heart is rendered naturalistically.

In the wider category of human property and objects from everyday life we find novel representations such as swords, tools and crops, though the most interesting items are the boats from Chios. They are the products of specific craftsmen whose names are incised on the objects, and one has the turgh $a^{60}$ imprinted on it (fig. 17). Stylistical affiliations in this morphological type are geographical rather than based on particular forms of object -for example, the same style is found in human figures, parts of the body and other items.

In this group there are two stylistic categories that come out clearly. ${ }^{61}$ One of these is represented by a number of offerings collected by the Paidousis in Ioannina, which have in common a broad frame hatched with diagonal lines. The other large category has no specific provenance, but it contains designs which are typical 
of the eastern Greek islands (Chios and Mytilene) and beyond (similar figures are found in Asia Minor ${ }^{62}$ ). They are round in shape and display recurring features in both the main subject and the decoration (fig. 18).

Decoration on embossed tamata is less stylised and more detailed. Crosses again predominate, though they now take a different form -linear, two-dimensional and square, similar to the so-called 'Byzantine' type. However more examples appear without crosses, a phenomenon that coincides with attempts at adopting a westernised style. ${ }^{63} \mathrm{~A}$ trend towards realism is apparent in offerings which depict details of clothing (jewellery, belts, stockings, shoes and laces).

With the introduction of technology, handmade tamata began to be replaced by stereotyped forms -pressed shapes, fashioned in a brass uterus. As more modern, mass-produced objects, they naturally form the largest group numerically, but they display less stylistic interest, and many items in the collection are identical. Here again different stylistic divisions can be distinguished, most obviously in a group of recent tamata still produced today; the collection contains representative examples of most objects included in this category.

Stylistic divisions in this category are mainly chronological, and are based on groups of objects, not individual items, an indication of the existence of specialised workshops with a distribution throughout Greece. Each group may take more than one form, no doubt because the objects were produced from different casts in different workshops. ${ }^{64}$

Pressed tamata display the same iconography as the embossed form, with certain variations. Most of the human figures hold a candle, a cross or a branch, symbolising purity and holiness. ${ }^{65}$ Women's dress, whether peasant costume or urban outfits conforming to European fashion, normally follows contemporary styles. ${ }^{66}$ Men are usually depicted in urban dress, though some wear military uniform. ${ }^{67}$ Pressed depictions of parts of the body and other objects have a standardised form.

Decoration forms an integral part of the design and is accordingly stereotyped: a ring-matted or flat background, with flowers or large dots in the corners, accompanies all subjects, animate or inanimate. Sometimes a cross with the name or initials of the votary is incised or hand-written, indicative of a wish or a "thank you". The purity of the silver $(800 \mathrm{gr})$ is stamped on some objects.
A very small number of objects are cast in special clay moulds, with the details rendered later by hand. The motifs in cast tamata are identical to the pressed, and it is possible to observe an overall continuity of form, a typological evolution where one form of offering copies another until all tamata are produced in a stereotyped manner, with virtually no attempt at individual creativity.

For the purposes of this article, discussion has been limited to a single typology based on the morphology and iconography of the objects. Although this categorisation is prima facie the most objective, being based on external appearance, other methods will need examination in the future and may prove of importance to our understanding of the subject.

\section{Classification}

Current literature on the subject of tamata has made virtually no attempt at producing a consistent typology; the only exception is Kardamitsi-Adami, who proposes a thematic grouping of tamata in parallel with a chronological classification based on female dress, ${ }^{68}$ and accordingly makes a division between rural and urban tamata. We have already seen however that these two categories may overlap, and will shortly be observing the difficulties of specific dating and the limitations of the methods of achieving it.

At the present time all we have to rely on for our information is the objects themselves and the techniques by which they were produced. The collecting of tamata was carried out in a spirit which saw them merely as curios suffused with ritual meaning, and this ensured that very little other evidence has survived. Few details were recorded which would enable us to obtain a more thorough appreciation of the objects in context: ${ }^{69}$ at the most we are told where they were found, and this does not necessarily coincide with the place of production. An additional problem derives from the fact that tamata were originally presented to churches and other sacred buildings, and collectors are therefore often reluctant to disclose how or from whom they were obtained.

\section{Dating}

Few intrinsic dating parameters on or about the objects exist, but a stylistic analysis of the material may enable us to arrive at a relatively accurate chronology.

The tamata we see in collections today were mainly 

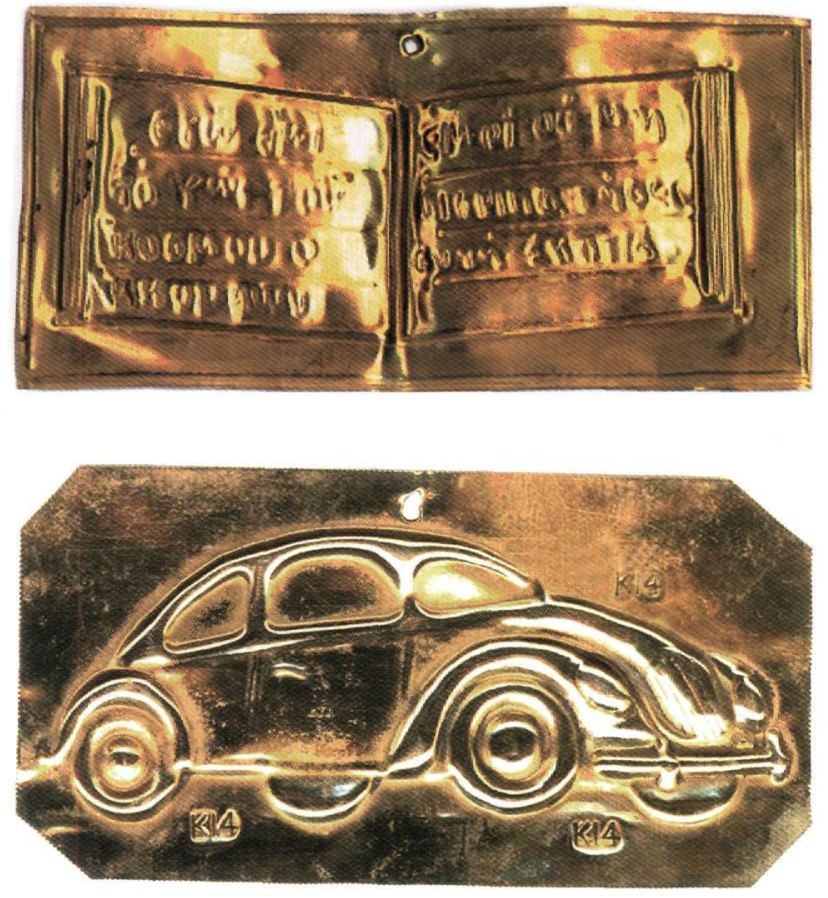

Fig. 23. Gold-plated rectangular tama with an embossed

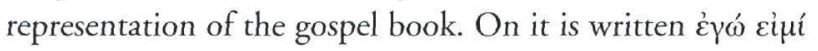

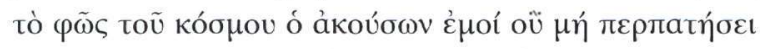

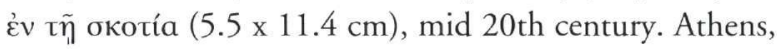
Benaki Museum 38319.

Fig. 24. Gold rectangular tama with a pressed representation of a car (VW Beetle). (4.5 x $8.4 \mathrm{~cm})$, mid

20th century. Athens, Benaki Museum 36420a.

produced between the late 19th and the mid-20th centuries. Very few offerings can be positively dated earlier than the second half of the 19th century; those which survive only did so because they were somehow forgotten, lost, or hidden, and thus escaped being dismembered for the recycling of their component parts or melted down to make new tamata or other ecclesiastical objects.

One element that may be of help in dating certain items is their iconography. According to KardamitsiAdami, for example, the fashion of dress depicted on human figures can reveal the period when the offering was made. While it is certainly the case that, as far as the 20 th century is concerned, female dress (village, urban or European) suggests the period when it was fashionable, the writer goes further and classifies all types of offering chronologically on this basis.
This line of reasoning may bring about misinterpretations. Firstly, iconography is often an arbitrary matter and subject to the interpretation of the viewer: what can be seen as a man in a palladium, for example, could also be a woman in a dress. Furthermore, it was common practice to reproduce figures even when they were "out of fashion". Stereotyped human figures, in particular, remained on the market for a long time after they began to be produced. ${ }^{70}$

The evolution from simple to more elaborate forms is also difficult to detect. Most probably there was no sudden switch, and parallel production was normal. What we can establish for certain is the period at which any attempt at making new designs ceased. Since the 1950 s there have been no new forms even of pressed tamata, and for this reason no figures exist which display contemporary iconography.

Against this background, it is clear that any figure could be reproduced at any period of time. For this reason, categorisation by style is more appropriate, as it may enable us to arrive at the date of production by making comparative studies of similar objects.

\section{Author and provenance}

As with the date, establishing the authorship and provenance of most surviving tamata is very difficult. To a great extent, tamata have always been the product of anonymous artists - not even artists in the conventional sense, in fact, since the votaries often made the offerings themselves. General metalworkers or specialists in other fields, such as watchmakers, also made tamata. In some ways they were utilitarian objects which occasionally could even be produced by priests.

This brings to light a further parameter affecting classification: on the one hand there are the clearly anonymous objects, products of households or small workshops; on the other, certain objects achieve a genuine individuality. So-called individuality can be established on two levels. The offerings may contain marks or features that are distinguishable as the work of individual makers, even though we may not know who the makers were; on another level, the votaries may add names, dates and messages, in a way that makes the objects personal and specifically directed to the saints.

Scholars agree that by the end of the nineteenth century, special workshops had began to be established, 
to whom the faithful entrusted the making of offerings. Traditionally, these were city workshops or small undertakings in the larger urban centres. Most writers state that Athenian workshops held the leading position in the market for the production of tamata, but this trend can only have been established in the twentieth century, as the history of neo-Hellenic traditional silverware provides no evidence for the existence of Athenian workshops before then.

Certain urban workshops such as those of Ioannina developed their own individual style, as mentioned earlier. The Kriss's book contains photographs of similar objects found in Corfu, ${ }^{71}$ and we know that there were trading links between the two areas, and that many silversmiths from the Pindos area had in fact moved to the Ionian Islands, ${ }^{72}$ factors which may enable us to locate and date the objects. Yet this is one of the few cases where we have substantial evidence both from the objects themselves and from written sources; for most other stylistic categories we have no knowledge of their provenance.

In discussions on silverware, classification tends to be based on regional styles. A basic and widely accepted distinction is made between mainland artefacts, which are considered to be more genuinely Greek, and those from the islands, which display greater external influences. ${ }^{73} \mathrm{~A}$ further distinction can be made between the products of small local workshops and those of more professional production centres which had a distribution throughout Greece. In similar fashion, tamatd were produced either locally or on a country-wide basis.

Yet there is a basic characteristic that distinguishes tamata from other metal artefacts. Jewellery, for example, as well as most gold and silverware, was a form of personal property, so that although it may have been produced relatively anonymously, a degree of information has survived to our own day. Tamata, on the other hand, never formed part of household effects, ${ }^{74}$ as they were given away as soon as they were produced. Despite occasional registration in church records, therefore, they are normally without identity.

It would appear therefore that the most satisfactory approach to the problem is through an investigation into the style of the objects concerned. Style depends on the taste and creativity of the maker, the artistic trends of his period and region, and the demands of the votary. A combination of all these elements should allow us to create a typology for all tamata, whether or not still produced today, based both on the appearance of the objects themselves and their place in the history of tamata production.

\section{Conclusion}

Much more could be said, and many further issues included in this discussion of tamata, on the subject of how they are made and of the wider social context in which they are used. Is any particular knowledge and value, technical or religious, inherent in the production of these objects? And, consequent on this, should we see them as works of art, or mere artefacts?

Another potential field of enquiry is the social and religious context within which tamata acquire meaning. What position do they hold in Greek Orthodox tradition? How do we account for the occurrence of similar practices around the world both now and in the past?

It might be interesting to conclude with a look at the current status of tamata. Votive offerings are still in use today. Their form has changed from handmade to mass-produced figures, with a consequent reduction in variety. ${ }^{75}$ The usage has diminished, and the ritual procedures are followed less faithfully. Nevertheless, offering is still regularly practised by faithful and active members of the Greek Orthodox church.

Tamata have acquired new meanings which have transformed their identity and introduced them into novel and unfamiliar surroundings. Academic enquiry has increased, and so has collection and exhibition. This triple interest has stimulated the antiquarian and even the humble vendor into becoming aware of their potential value, and this in turn has led to certain objects coming on to the market with the label (and also the price) of collectibles. Churches also exhibit them, with a hint of spirituality, as living proof of miraculous divine intervention. Thus while in the past they were simply considered as a medium for communication with the divine, tamata have today acquired an intrinsic value as objects in their own right. For some their value lies in their form, for others in their function.

In this article I have tried to account for the significance of tamata both as works of art and as religious objects. In both cases they have been underestimated, but for different reasons: in the first case the problem is their inferior aesthetic and technical quality by com- 
parison with the richness of other traditional Greek artefacts, in the second the ambiguous status of votive practices in Greek Orthodoxy, which derives from their magical and pagan character. I would therefore like to sum up this article with the contention that, contrary to the views of some earlier writers, there is a great deal

\section{Notes}

1. Other donors of tamata to the Benaki Museum are: the Exchange of Populations Fund, 1931-1933, 22 objects; the Friends of the Benaki Museum, 1979, 9 objects; Alekos Fassianos, 1984, 47 objects; Athina Kalogeropoulou, 1994, 7 objects; Markar Sirapian, 1999, 2 objects; Angelos Delivorrias, 2000, 10 objects.

2. These include a Turkish coin, a flask cover dated 1714 , two xaïua $ı a ́$ (animal talismans) and a small ivory pendant depicting a saint.

3. 112 women, 1 woman and child, 54 men, 74 young women and girls, 76 young men and boys, 1 boy and girl holding hands and 3 more children, 30 babies, 25 soldiers, 15 angels and 59 humans of indeterminate sex.

4. 154 eyes, 95 legs, 85 hands, 50 heads, 44 torsos, 43 stylised hearts, 1 naturalistic heart, 32 ears, 8 breasts, 3 mouths, 3 fingers, 1 tongue, 1 abdomen, 1 bone and 1 spine.

5. 28 houses, 1 representation of the Parthenon, 8 keys, 9 cars, 1 aeroplane and 18 boats; 2 books, 1 diploma (tied together with two eyes), 5 tools (scissors, a ladder and 3 measurement tools), 1 crop (a bean); 3 envelopes, 3 "thank you" notes, 19 wedding garlands, 2 horseshoes, 2 swords, 2 belts, 1 miniature shoe and 2 life-size shoes. (Paidousis commissioned these last from a metalworker in Monastiraki so as to have in his collection examples of the shoes traditionally offered to the Taxiarchis of Mytilene.)

\section{3 crowns, 2 halos, 10 hands, 1 heart and 1 leg.}

7. In actual fact metal is never $100 \%$ pure, and when we talk of pure silver objects, we mean those whose main ingredient is silver. I am grateful to Ginia Karydi for this observation.

8. Collecting from churches has always been a controversial issue, which is one reason why many tamata collections are kept private.

9. Mikes Paidousis was a distinguished haematologist, who founded the Red Cross centre for blood donation in Greece. $\mathrm{He}$ was also an active collector and man of letters, with many publications to his name.

10. 6 boats are exhibited in gallery 30 (case 2) and gallery to say about tamata and the position they occupy in contemporary Greek society.

\author{
Sophia Handaka \\ Benaki Museum \\ e-mail:handaka@benaki.gr
}

31 (case 1); 21 human figures and 4 animals in gallery 32 (cases 2 and 3); 4 houses and 4 heads in gallery 32 (case 5).

\section{V. Diamantis, Ta Táuata (Athens 1999) 9.}

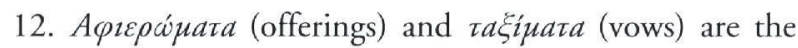
most common synonyms used. There are also other terms

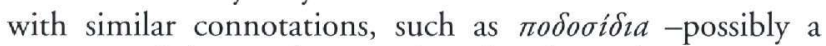

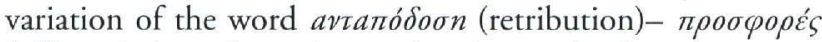
(offertories), and xapífuata (remitments); these latter are commonly found in Crete. They are also called $\sigma v v \delta \rho o \mu \varepsilon s$

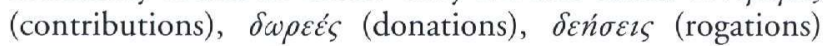
and Swpiopata (gifts). All these words incorporate in their meaning the act of offering, but other expressions indicate the place where the tamata are placed in the church: in

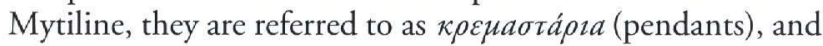

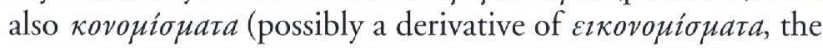
stem of which is Eıkóva [icon], but which could also refer to vouífuata [coins]). In Euboea and Paros, among other

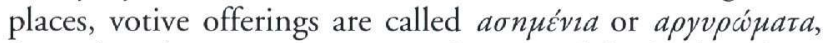

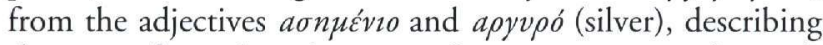
the type of metal used to manufacture tamata; such words mainly refer to the material form of the object. Tamata are also known locally as r (weaklings) and aonuónar $\delta$ a (silver children); in the last two cases it is the figure represented that gives the object its name, although the term can be used generally for objects which do not depict humans; see Diamantis (n. 11) 10; M. Kardamitsi-Adami, Táuaza - Eáuaza (Athens 1996)

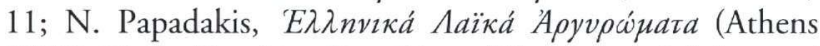

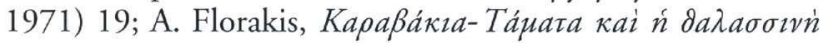

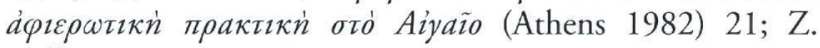

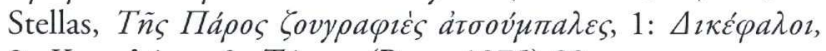

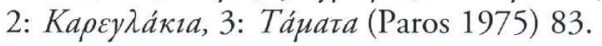

13. I have tried to avoid using the Latin term ex-voto (literally 'according to what was promised'; J. de Pina-Cabral, Sons of Adam, daughters of Eve [Oxford 1986] 163-64 or 'from a vow'; M. Egan, Milagros: Votive offerings from the Americas [Santa Fe 1991]), even though it may sound more familiar to the non-Greek reader. This is because, while metal and wax effigies existed all over the world, the expression exvoto is also widely associated with other forms of offering paintings, woodcarvings, statues and other three-dimensional 
objects- which are not commonly found in Greece. In western countries such as France, England, Germany and the Netherlands, the practice has now disappeared, though it still continues in strongly Catholic communities like Portugal, Spain, southern Italy and Latin America. For more on this subject, Ex-voto Fribourgeois (exhibition catalogue, Musée d' Art et d' Histoire de Fribourg, Fribourg 1978); S. Butler, Exvoto (London 1928); B. Cousin, Ex-voto de Provence: Images de la religion populaire et de la vie d'autrefois (Desclée de Brouwer 1981); Egan (ibid.); G. Manganelli, G. Guadalupe, Ex-voto: Storie di miracoli e di miracolati (Parma 1975).

\section{Papadakis (n. 12) 23.}

15. For manifestations of this at the Church of the Annunciation in Tinos, J. Dubisch, In a different place: Pilgrimage, gender, and politics at a Greek island shrine (New Jersey 1995) 76-100.

16. The latter was common in the case of children in need of divine protection. They were offered for long periods and were dressed in black. As a mark of their enslavement -also known as selling $(\pi \dot{\omega} \lambda n \sigma n)-$ they wore around their necks or wrists for the full period of their service a bell, a silver or brass ring, or sometimes even a votive offering depicting the afflicted organ. This was held to be a sign of their debt to the divinity, to be repaid in the years to come. Sometimes repayment literally took place; people had to collect enough money to pay for their 'freedom'. When the time came for freedom to be granted, prayers were read and the object was removed and offered to the saint, and was usually placed in the church beside other votive offerings. Kyriakides mentions an oral account by a woman from Constantinople who had been 'enslaved' as a child. One night she dreamt of a man coming to her protection on a white horse; the next day she fell down and broke her head. When she told the dream to her mother and aunt, they recognised the horseman as St George Koudounas (the 'Bell'-Man, from Pringhipos Island, Constantinople), who had protected her from a fatal accident. As a result the girl was offered to the saint until the age of fifteen, during which period she wore a small bell hanging around her neck. At fifteen the girl was freed from her enslavement. She was taken to church, where the priest read certain spells and the bell was offered back to the saint,

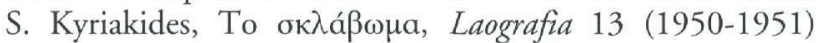
351-52. The practice still exists today. The Benaki Museum contains seven rings recorded as tamata for mentally deranged people, which were donated by the Exchange of Populations Fund.

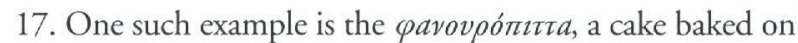
the feast-day of Agios Fanourios (27th August), a saint believed

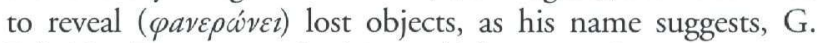

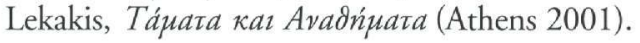

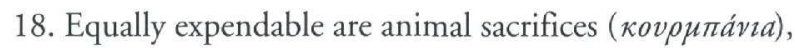
yet in this case focus shifts to the consumable quality of the offerings. Such practices are still extant, or have been revived, in certain parts of Greece such as the island of Mytilene, but their symbolism is less obvious than in former times.
19. General Makryiannis recounts the moment he felt wronged and decided to "make a deal with the saint". He was 14 years old: "I went into the church at night, locked the door and began to cry out with loud exclamations and cries of repentance. 'What has happened to me? I'm a donkey whom they are beating'. And I called on him to give me fine silver weapons and 15 wallets of money and I would make him a big silver candlestick. We made our agreement with the saint in a loud voice. Soon after this my master's brother wrote from Ioannina that his boss wanted a boy to help him. They sent me there in 1811" (The reminiscences of Makryannis I [Athens 1992] 71).

20. Certain offerings are associated with particular icons; usually these are representations of the hands or feet of the relevant figure, e.g. the hand of the Virgin Mary embracing the baby Christ, the hand of Christ raised in blessing, and that of the equestrian saints Dimitrios and Georgios holding a spear.

21. See the introduction to the Greek edition of Megas' book on Greek calendar customs, where the writer notes that he has not included those elements of popular worship in common use -including tamata- because they are generally

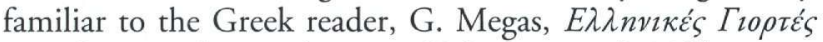

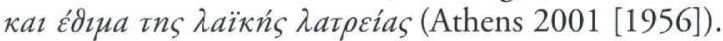

22. For an excellent study of ancient Greek votive offerings, F. T. van Straten, Gifts for the gods, in: H. S. Versnel (ed.), Faith, hope and worship: Aspects of religious mentality in the ancient world (Leiden 1981) 65-151.

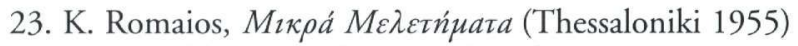
42-47. First published in the journal Meleti in 1909.

24. Quoted in M. Kardamitsi-Adami, Tápata - $O^{\prime} A v$

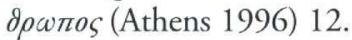

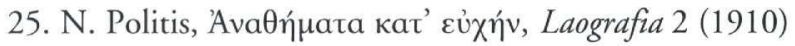
$125-50$.

26. R. Kriss, H. Kriss, Peregrinatio neohellenica. Wallfahrtswanderungen im heutigen Griechenland und in Unteritalien, mit 126 Bildern (Wien 1955).

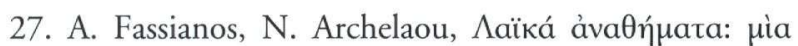

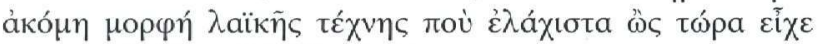

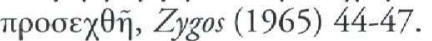

28. Papadakis (n. 12): It is interesting to note that on the first page of his book, Papadakis specifically allows free and unrestricted use of the information contained in the book: "The purpose of works of this type is to provide information, and for this reason they are not the private property of the author or the collector or the photographer or anyone else. The intellectual property belongs to anyone who wishes to continue research into the anonymous art of our people. Use of the whole or part of the text or the photographs is freely permitted without obtaining the author's permission or making reference to his work".

29. Papadakis, who considers dotted tamata to be the most genuine popular artefacts, notes that due to the strongly religious nature of the objects, they were not influenced by general artistic movements, nor by orientalising or other trends 
arising from the Turkish occupation, Papadakis (n. 12) 34 .

30. Papadakis (n. 12) 116.

31. Such as the theory that there are no surviving offerings in the shape of boats because people threw them into the sea, Papadakis (n. 12) 115-16 n. 104.

32. Such as the absence of crosses on certain figures, a mark of western stylistic influences, Papadakis (n. 12) 113 n. 65 .

$$
\begin{aligned}
& \text { 33. Stellas (n. 12). } \\
& \text { 34. Stellas (n. 12) } 83 . \\
& \text { 35. Stellas (n. 12) } 92 . \\
& \text { 36. Florakis (n. 12). }
\end{aligned}
$$

37. Certain other studies are not mentioned here, as they do not make a significant contribution to the study of votive offerings.

38. She also comments that the creation of what we consider art is not always a conscious act of the craftsman. A potter, woodcarver, smith, weaver or embroiderer often make a utilitarian object which they subsequently decorate, Kardamitsi-Adami (n. 24) 13.

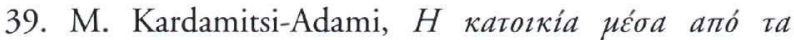

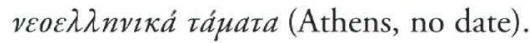

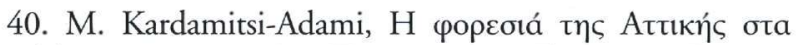

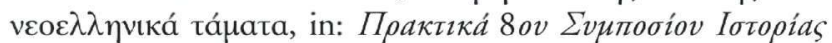

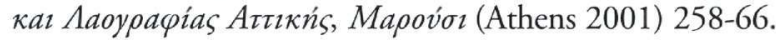

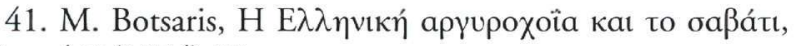
Zygos 4-7 (1974) 85.

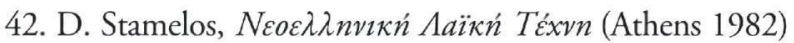
33.

43. Y. Kaplani, Modern Greek Silverware from the Collections of the Museum of Greek Folk Art (Athens 1997) 51.

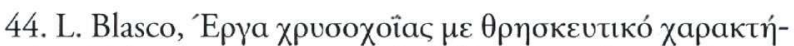

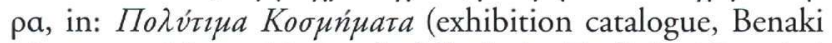
Museum - Museo Nazionale delle Arti e Tradizioni Popolari in Rome, Athens 1988) 49-51.

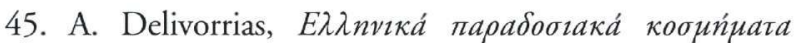
(Athens 1979).

46. Usually a mixture of tar, sand and grained marble, which is soft but durable, Kardamitsi-Adami (n. 40) 259.

47. In the Mikes Paidousis collection, it is possible to recognise particular styles as being common to objects which are recorded as collected in the same area.

48. Still, the sex is not always clear. Many of the objects seem to be wearing a skirt, but their number is probably too large to permit the assumption that this triangular shape necessarily represents a female figure. In any case, some 'skirted' figures have male characteristics such as a moustache, while others distinguish the male by a small incision between the legs. The figures which are clearly male are thinner and longer, wear trousers and often have their hands in their pockets.

49. For more on dress, Kardamitsi-Adami (n. 40).

50. Papadakis (n. 12) 110 n. 39.

51. The latter may be a discreet reference to indelicate parts of the body. Various views have been expressed concerning 'venereal' offerings, which were usually presented by sailors afflicted with venereal diseases. Such offerings were seldom displayed in churches, and they were sometimes hidden in holes in church walls, or kept aside by the priests. In view of this, and also in the spirit of a particularly personal interaction and understanding with the saints, people offered these representations in a disguised form, generally eyes for female genitals and fingers for the male (I am grateful to Maria Argyriadi for information about the concealment of tamata in church).

52. The latter resemble stomachs, yet similar objects are found as coverings on a 16th century icon, where they represent the breasts of the Virgin Mary: Ceremony and faith. Byzantine art and the Divine Liturgy (exhibition catalogue, Hellenic Antiquities Museum, Melbourne - Hellenic Ministry of Culture, Athens, May-October 1999) 116 fig. 11. M. Kardamitsi-Adami informed me that certain offerings shaped like eyes may in fact sometimes represent female nipples.

53. In his book on Greek customs, D. Loukatos mentions Agia Zoni (literally the Saint of the Belt), celebrated on the 31 st of August, a saint who represents the holy belt of the Virgin Mary which was found in Cappadocia and brought to Constantinople to be kept with other sacred relics. Mothers take thread to the liturgy in the church of Aghia Zoni to be sanctified and then 'belt' their children with it so that they grow up strong and healthy. According to A. Adamantiou, the worship of Aghia Zoni exemplifies devotion to the virginity of Mary (A. Adamantiou, Aүveíac Пzípa, Laografia 2 [1910] 526). If this is the case, the 'belt' may be said to be a symbolic representation of virginity, $\mathrm{D}$. Loukatos, $T a$

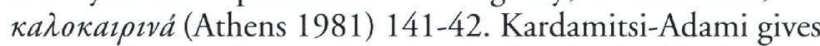
an equally possible explanation in her book, KardamitsiAdami (n. 12) 26.

54. Incision is the easiest method of creating individual designs; makers often use ready-made framed plaques which they complete with the design requested by the votary, a practice still in force today in certain workshops in Tinos. This is also the case with embossed offerings; the objects from Ioannina were probably made by this method (see below).

55. According to Yiona Paidousis, it was offered in Spetses by the family of a well-known professor who had had problems with his eyes while studying at university.

\section{Kardamitsi-Adami (n. 24) 10.}

57. Every feature of these offerings suggests this: the position of the hands is identical to that of saints in icons, the style is typical of ecclesiastical art, and the multiple holes around the frame reveal that they were intended to be nailed on to icons. 
58. Babies are normally shown in swaddling clothes. Boys and teenagers are dressed in nautical shirts or jackets and shorts. Young girls wear dresses, and sometimes hats, and their skirts become longer as they grow older. Older women wear long one or two-piece garments and have elaborate hairstyles, while older men are dressed in long trousers and many have a moustache.

59. For offerings from Italy, Blasco (n. 44).

60. The signature of the sultan.

61. There may well be further categories which have not yet been identified, for example a group of objects that share morphological (colour and texture of the metal) and technical characteristics (frame and maker's mark).

62. G. Kürkman, Ottoman Silver Marks (İstanbul 1996) 216, 218.

63. Papadakis (n. 12).

64. Kardamitsi-Adami (n. 24) 15-16.

65. Kardamitsi-Adami (n. 24) 18.

66. See for example the introduction of the corset to make women look slimmer, and the appearance of women in suits.
67. Offered mainly during wartime.

68. Florakis suggests as a further classification the social class of the people who make the offering; however this was only possible because he was dealing with one type of offering, and we do not yet have enough evidence to suggest that this social parameter can be used as a general classification, Florakis (n. 12) 87 .

69. A similar attitude exists in stamp and matchbox collecting.

70. For example, we find offerings produced today with a design which first appeared in the middle of the 20th century.

71. Kriss, Kriss (n. 26) 8-9.

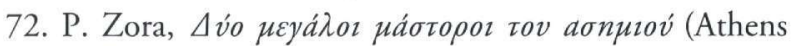

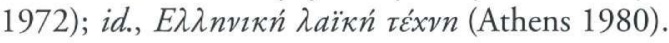

73. Kaplani (n. 43).

74. Except in cases where people kept the offerings on their private icon-stands at home.

75. Typical forms today are men, women, houses, eyes, hearts, hands and feet.

\section{¿OФIA XAN $\triangle$ AKA}

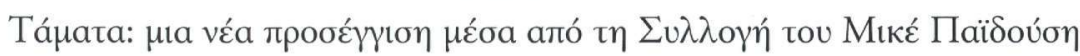

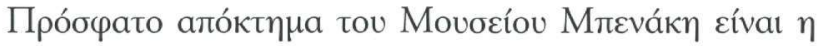

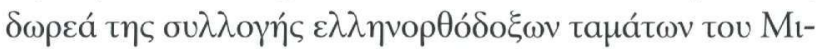

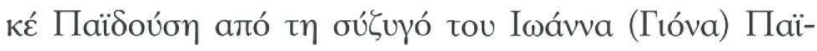

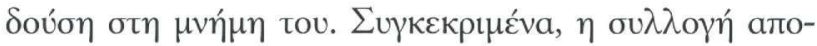

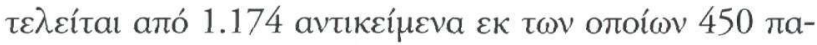

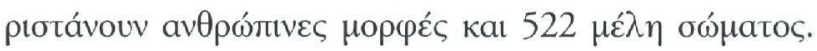

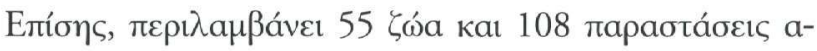

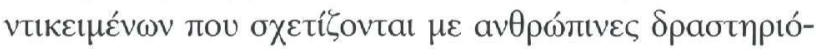

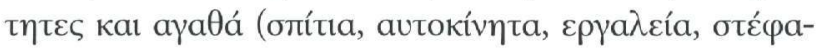

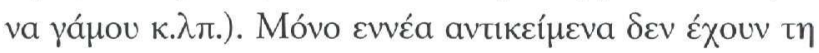

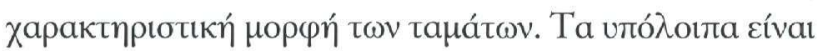

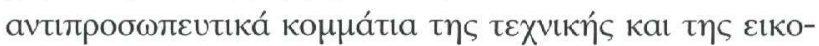

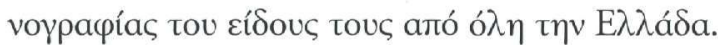

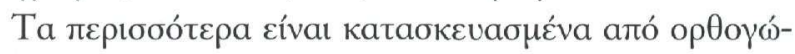

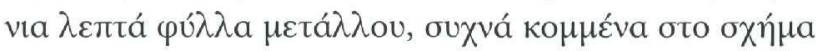

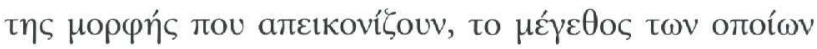

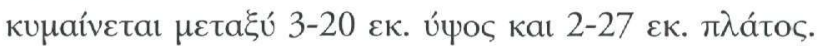

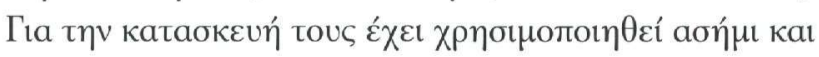

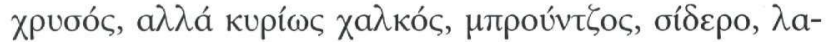

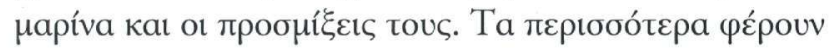

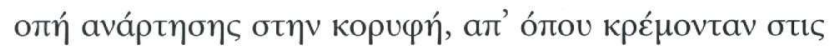

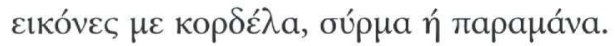

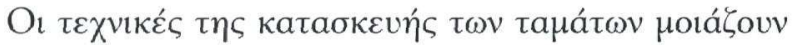

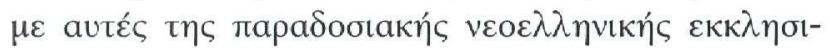

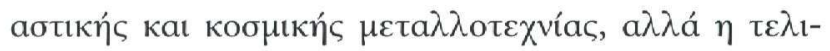

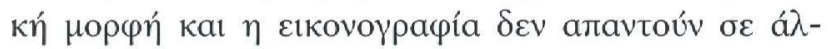

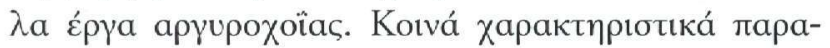

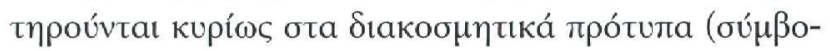

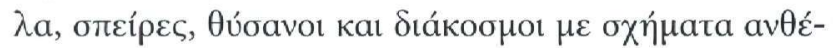

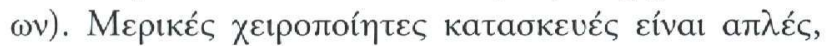

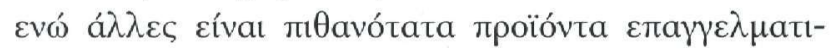

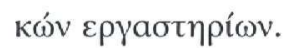

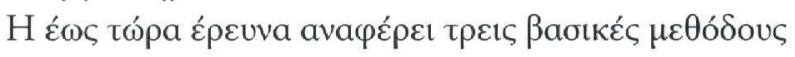

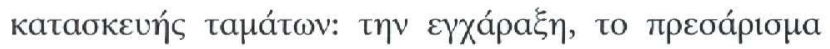

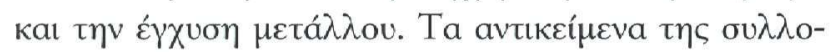

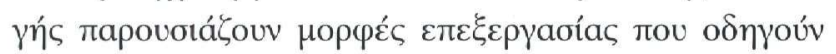




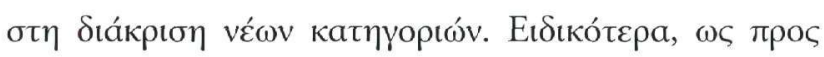

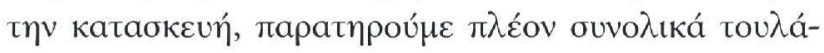

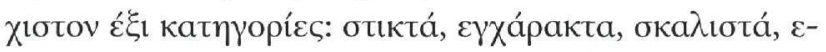

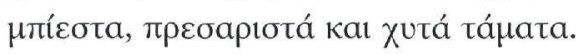

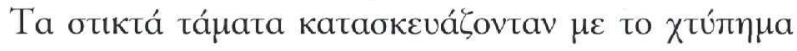

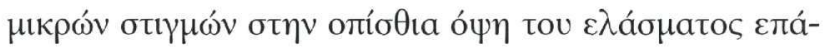

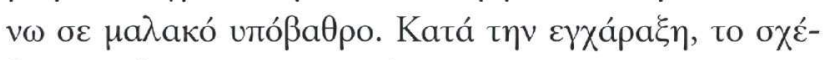

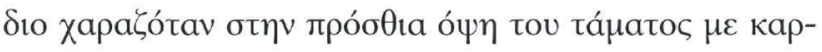

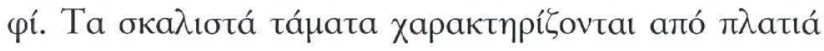

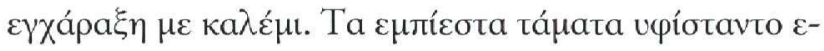

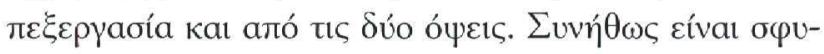

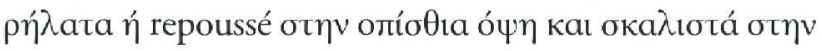

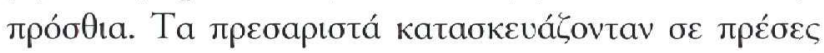

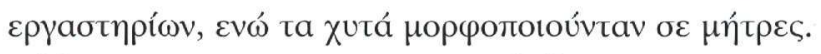

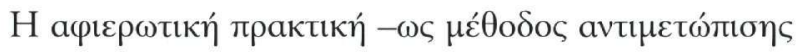

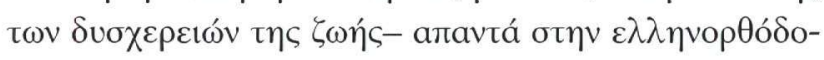

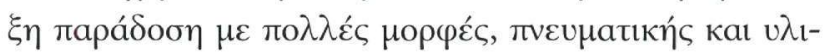

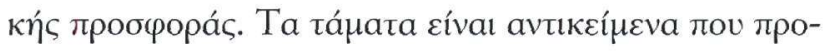

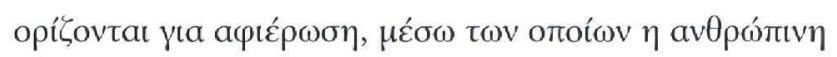

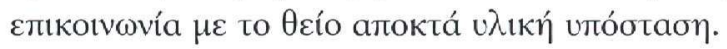

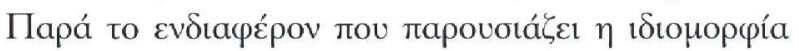

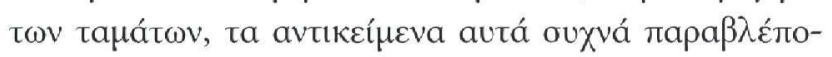

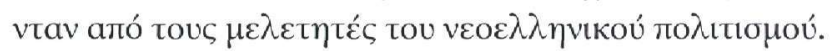

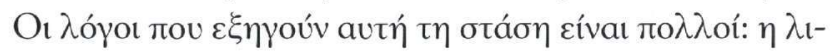

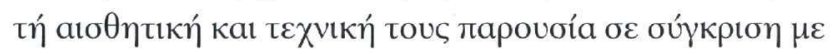
á $\lambda \lambda \varepsilon \varsigma$ ५

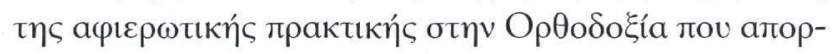

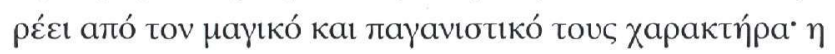

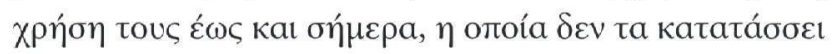

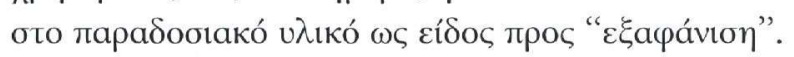

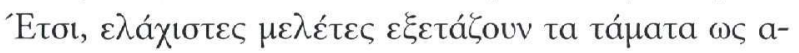

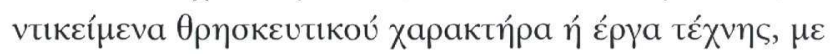

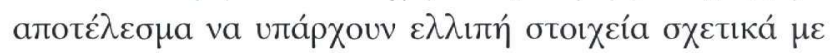

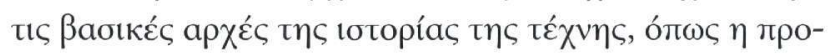

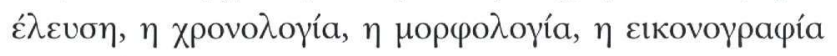
кaı to úpos tovs. 